\title{
BAB I
}

\section{PENDAHULUAN}

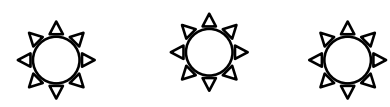

\section{$r$}

ata kelola Perusahaan (Corporate Governance) menjadi salah satu isu yang semakin popular di Indonesia. Banyak perusahaan telah menggunakan Corporate Governance sebagai rujukan dalam menjalankan perusahaannya. Dalam dunia global seperti sekarang ini, dimana tingkat persaingan yang semakin ketat mengharuskan perusahaan-perusahaan mengelola perusahaannya dengan professional. Demikian pula investor dalam mencari alternatif untuk berinvestasi, selalu mencari perusahaan yang dikelola dengan professional.

Banyaknya skandal yang telah terjadi diperusahaan menunjukkan bahwa perusahaan tersebut tidak dikelola dengan profesional. Skandal 
tersebut terjadi banyak diakibatkan oleh tidak dipatuhinya atau tidak dilaksanakan prinsip-prinsip corporate governance. Diantara skandal yang terjadi salah satunya diakibatkan oleh tidak transparannya pengelola perusahaan (Agent) dalam memberikan informasi terkait dengan perusahaan.

Tujuan dari Corporate Governance adalah untuk menciptakan nilai tambah bagi semua pihak yang berkepentingan (stakeholders). Secara teoritis, pelaksanaan corporate governance dapat meningkatkan nilai perusahaan, dengan meningkatkan kinerja keuangan mereka, mengurangi risiko yang mungkin dilakukan oleh dewan komisaris dengan keputusan-keputusan yang menguntungkan diri sendiri dan umumnya good corporate governance dapat meningkatkan kepercayaan investor.

Indonesia mulai menerapkan prinsip GCG sejak menandatangani letter of intent (LOI) dengan IMF, yang salah satu bagian pentingnya adalah 
pencantuman jadwal perbaikan pengelolaan perusahaan-perusahaan di Indonesia (YPPMI \& SC, 2002). Sejalan dengan hal tersebut, Komite Nasional Kebijakan Corporate Governance (KNKCG) berpendapat bahwa perusahaanperusahaan di Indonesia mempunyai tanggung jawab untuk menerapkan standar GCG yang telah diterapkan di tingkat internasional.

Struktur buku ini terdiri dari Bab I yang berisi tentang latar belakang pentingnya corporate Governance. Pada Bab II membahas tentang pengertian corporate governance dan tujuannya. Sementara pada Bab III membahas tentang sejarah dan perkembangan corporate governance. Pada Bab IV buku ini membahas tentang prinsip-prinsip corporate governance. Pada Bab $\mathrm{V}$ membahas tentang struktur corporate governance, dan yang terakhir Bab VI membahas tentang pedoman umum pelaksanaan corporate governance serta perbandingan pelaksanaan di beberapa Negara Asia. 


\section{BAB II}

\section{PENGERTLAN CORPORATE GOVERNANCE}

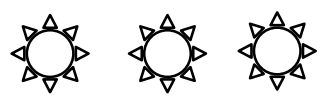

\section{A. Pengertian dan Tujuan Good Corporate Governance}

Terdapat banyak defenisi terkait dengan corporate governance. Corporate governancei didefenisikan dengan luas sesuai dengan kepentingan institusi, penulis, Negara dan tradisi yang menggunakan istilah tersebut.

IFC mendefenisikan corporate governance sebagai sebuah struktur dan proses dalam menentukan arah dan pengawasan terhadap perusahaan. Sementara Organization for Economic Cooperation and Development (OECD) mendefenisikan corporate governance sebagai berikut :

" The internal means by which corporation are operated and controlled, which involve a set of 
relationship between a company's management, its board, its shareholder and other stakeholder. Corporate governance also provides the structure through which the objectives of the company are set, and the means of attaining those objectives and monitoring performance are determine. Good corporate governance should provide proper incentives for the board and management to persue objectives that are in the interests of the company and shareholders and should facilitate effective monitoring, thereby encouraging firms to use resources more efficiently."

Kebanyakan defenisi hanya terpusat pada perusahaan itu sendiri (dalam perspektif internal), namun hal tersebut mempunya elemen yang dapat didefenisikan secara umum sebagai berikut :

> Corporate governance merupakan sebagai hubungan system yang terdiri dari struktur dan proses. Contoh, hubungan antara pemilik saham, manajemen dan stakeholder yang terdiri dari hubungan antara penyedia modal, stakeholder dan manajemen untuk menerima 
tingkat pengembalian dan laba atas investasi yang mereka tanamkan.

> Bagian dan Kepentingan yang Berbeda. Perbedaan kepentinggan antara berbagai organ dalam perusahaan seperti dewan direksi dan dewan komisaris. Perbedaan kepentingan antara pemilik perusahaan dengan pengelola perusahaan dimana secara umum merupakan masalah principal-agent.

> Semua bagian berperan dalam menentukan arah dan pengawasan perusahaan. RUPS, pemegang saham yang mewakili, mengambil keputusan yang mendasar, misalnya pembagian keuntungan. Dewan Komisaris secara umum bertanggung jawab terhadap bimbingan dan pengawasan, menerima strategi perusahaan dan mengendalikan direksi. Direksi, akhirnya, menjalankan operasi sehari-hari, seperti pelaksanaan strategi, penyusunan rencana bisnis, mengelola sumber daya manusia, mengembangkan strategi pemasaran dan penjualan, dan mengelola aset. 
Gambar 1. Sistem Corporate Governance

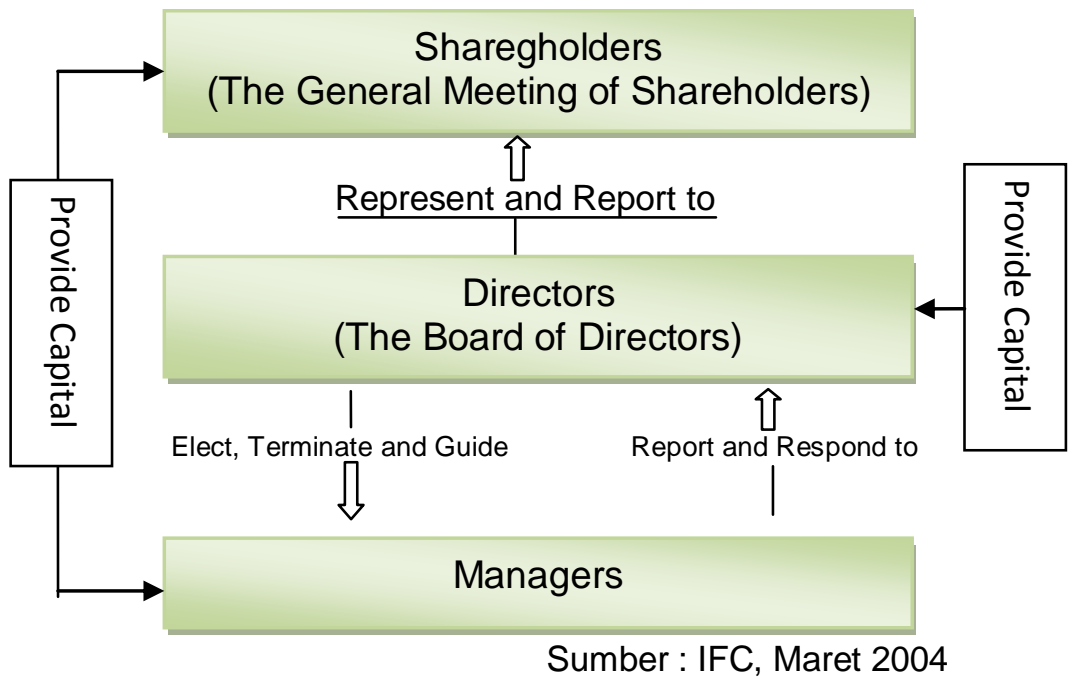

Menurut FCGI (2001) pengertian Good Corporate Governance adalah seperangkat peraturan yang mengatur hubungan antara pemegang saham, pengurus (pengelola) perusahaan, pihak kreditur, pemerintah, karyawan serta para pemegang kepentingan intern dan esktern lainnya yang berkaitan dengan hak-hak dan kewajiban mereka atau dengan kata lain suatu sistem yang mengatur dan mengendalikan 
perusahaan. Sedangkan menurut Cadbury Committee adalah seperangkat aturan yang merumuskan hubungan antara para pemegang saham, manajer, kreditor, pemerintah, karyawan, dan pihak-pihak yang berkepentingan lainnya baik internal maupun eksternal sehubungan dengan hak-hak dan tanggung jawab mereka.

Menurut Rahmawati (2006) dalam Putri (2006) Good Corporate Governance didefinisikan sebagai seperangkat aturan dan prinsip-prinsip antara lain fairness, transparancy, accountability dan responsibility, yang mengatur hubungan antara pemegang saham, manajemen, perusahaan (direksi dan komisaris), kreditur, karyawan serta stakeholders lainnya yang berkaitan dengan hak dan kewajiban masing-masing pihak. Berdasarkan definisi atau pengertian good corporate governance di atas dapat disimpulkan bahwa, pada dasarnya good corporate governance adalah mengenai sistem, proses, dan seperangkat peraturan yang mengatur hubungan antara berbagai pihak yang berkepentingan (stakeholders) terutama dalam arti 
sempit hubungan antara pemegang saham, dewan komisaris, dan dewan direksi demi tercapainya tujuan perusahaan.

Sedangkan tujuan dari good corporate governance adalah untuk menciptakan nilai tambah bagi semua pihak yang berkepentingan (stakeholders). Secara teoritis, pelaksanaan good corporate governance dapat meningkatkan nilai perusahaan, dengan meningkatkan kinerja keuangan mereka, mengurangi risiko yang mungkin dilakukan oleh dewan komisaris dengan keputusankeputusan yang menguntungkan diri sendiri dan umumnya good corporate governance dapat meningkatkan kepercayaan investor (Tjager, et al., 2003).

Menurut Organisasi Kerja Sama Ekonomi dan Pembangunan (1999) bahwa defenisi Corporate Governance sebagai berikut :

"Cara internal dengan mana perusahaan dioperasikan dan dikendalikan [...], yang melibatkan satu set hubungan antara manajemen perusahaan, dewan, pemegang saham dan lainnya pemangku 
kepentingan. Tata kelola perusahaan juga menyediakan struktur melalui mana tujuan perusahaan diatur, dan cara mencapai tujuan tersebut dan pemantauan kinerja ditentukan. Tata kelola perusahaan yang baik harus memberikan insentif yang tepat untuk papan dan manajemen untuk mengejar tujuan-tujuan yang berada di kepentingan perusahaan dan pemegang saham, dan harus memfasilitasi pengawasan yang efektif, sehingga mendorong perusahaan untuk menggunakan sumber daya yang lebih efisien.

\section{B. Manfaat Penerapan Corporate Governance}

Pelaksanaan good corporate governance diharapkan dapat memberikan beberapa manfaat berikut ini (FCGI, 2001):

1) Meningkatkan kinerja perusahaan melalui terciptanya proses pengambilan keputusan yang lebih baik, meningkatkan efisiensi operasional perusahaan serta lebih meningkatkan pelayanan kepada stakeholders. 
2) Mempermudah

diperolehnya

dana pembiayaan yang lebihmurah sehingga dapat lebih meningkatkan corporate value.

3) Mengembalikan kepercayaan investor untuk menanamkan modalnya di Indonesia.

4) Pemegang saham akan merasa puas dengan kinerja perusahaan karena sekaligus akan meningkatkan shareholders value dan dividen.

Pelaksanaan good corporate governance dilakukan dengan menggunakan prinsip-prinsip yang berlaku secara internasional, yaitu (FCGI, 2001). Prinsip-prinsip tersesbut adalah :

1) Hak-hak para pemegang saham, yang harus diberi informasi dengan benar dan tepat pada waktunya mengenai perusahaan, dapat ikut berperan serta dalam pengambilan keputusan atas perusahaan, dan turut memperoleh bagian dari keuntungan perusahaan.

2) Perlakuan sama terhadap pemegang saham, terutama kepada pemegang saham 
minoritas dan pemegang saham asing, dengan keterbukaan informasi yang penting serta melarang pembagian untuk pihak sendiri dan perdagangan saham oleh orang dalam (insider trading).

3) Peranan pemegang saham harus diakui sebagaimana ditetapkan oleh hukum dan kerjasama yang aktif antara perusahaan serta para pemegang kepentingan dalam menciptakan kesejahteraan, lapangan kerja dan perusahaan yang sehat dari aspek keuangan.

4) Pengungkapan yang akurat dan tepat pada waktunya serta transparasi mengenai semua hal yang penting bagi kinerja perusahaan, kepemilikan, serta para pemegang kepentingan (stakeholders).

5) Tanggungjawab pengurus dalam manajemen, pengawasan manajemen serta pertanggungjawaban kepada perusahaan dan para pemegang saham. 
Sistem tatakelola organisasi perusahaan yang baik, menuntut dibangun dan dijalankannya prinsip-prinsip tata kelola perusahaan (Good Corporate Governance) dalam proses manajerial perusahaan. Dengan mengenal dan sekaligus menerapkan prinsip-prinsip yang berlaku secara universal ini diharapkan perusahaan dapat hidup secara berkelanjutan dan memberikan manfaat bagi para stakeholdernya.

Indonesia mulai menerapkan prinsip GCG sejak menandatangani letter of intent (LOI) dengan IMF, yang salah satu bagian pentingnya adalah pencantuman jadwal perbaikan pengelolaan perusahaan-perusahaan di Indonesia (YPPMI \& SC, 2002). Sejalan dengan hal tersebut, Komite Nasional Kebijakan Corporate Governance (KNKCG) berpendapat bahwa perusahaanperusahaan di Indonesia mempunyai tanggung jawab untuk menerapkan standar GCG yang telah diterapkan di tingkat internasional. Namun, walau menyadari pentingnya GCG, banyak pihak yang melaporkan masih rendahnya perusahaan yang 
menerapkan prinsip tersebut. Masih banyak perusahaan menerapkan prinsip GCG karena dorongan regulasi dan menghindari sanksi yang ada dibandingkan yang menganggap prinsip tersebut sebagai bagian dari kultur perusahaan. 


\section{BAB III}

\section{PERKEMBANGAN CORPORATE}

\section{GOVERNANCE}
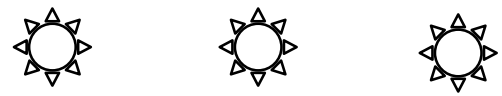

Dalam uraian tentang Agency Theory di atas disebutkan bahwa adanya perilaku dari manajer/ agen untuk bertindak hanya untuk menguntungkan dirinya sendiri dengan mengorbankan kepentingan pihak lain/pemilik, dapat terjadi karena manajer mempunyai informasi yang lengkap mengenai perusahaan, sedangkan informasi tersebut tidak dimiliki oleh pemilik perusahaan (dalam hal ini timbul Asymmetric Information atau A).

Adanya Al dan self serving behavior pada manajer/agen, memungkinkan mereka untuk mengambil keputusan dan kebijakan yang kurang bermanfaat bagi perusahaan. Adanya kondisi ini menimbulkan tata kelola perusahaan yang kurang sehat karena tidak adanya keterbukaan dari 
manajemen untuk mengungkapkan hasil kinerjanya kepada prinsipal sebagai pemilik perusahaan. Agency Theory menganalisis dan mencari solusi atas dua permasalahan yang muncul dalam hubungan antara para principal (pemilik/pemegang saham) dan agent mereka (manajemen).

Bila dilihat dari perkembangan teori perusahaan dan hubungannya dengan kebutuhan GCG, dari perspektif Agency Theory, tabel 2 berikut ini menunjukkan perkembangan akan kebutuhan GCG pada teori korporasi klasik, modern, dan postmodern.

Istilah Corporate Governance (CG) pertama kali diperkenalkan oleh Cadbury Committee tahun 1992 dalam laporannya yang dikenal sebagai Cadbury Report (Tjager dkk., 2003). Terdapat banyak definisi tentang $C G$ yang pendefinisiannya dipengaruhi oleh teori yang melandasinya. Perusahaan/korporasi dapat dipandang dari dua teori, yaitu (a) teori pemegang saham (shareholding theory), dan (b) teori stakeholder (stakeholding theory). 
Tabel 3.1. Perkembangan Teori Korporasi dan Implikasinya Terhadap Good Corporate Governance

\begin{tabular}{|c|c|c|}
\hline $\begin{array}{c}\text { TEORI } \\
\text { KORPORASI } \\
\text { KLASIK }\end{array}$ & $\begin{array}{c}\text { TEORI } \\
\text { KORPORASI } \\
\text { MODERN }\end{array}$ & $\begin{array}{c}\text { TEORI } \\
\text { KORPORASI } \\
\text { POST-MODERN }\end{array}$ \\
\hline $\begin{array}{l}\text { KARAKTERISTIK: } \\
\text { 1. Perusahaan } \\
\text { de-ngan single- } \\
\text { majo-rity } \\
\text { shareholders. } \\
\text { 2. Prinsipal me- } \\
\text { rangkap } \\
\text { sebagai Agen. } \\
\text { 3. Keseimbangan } \\
\text { kepentingan } \\
\text { antara prinsipal } \\
\text { dan agen tidak } \\
\text { penting. } \\
\text { IMPLIKASI: } \\
\text { Aspek Good } \\
\text { Cor-porate } \\
\text { Governance } \\
\text { TIDAK } \\
\text { diperlukan. }\end{array}$ & $\begin{array}{l}\text { KARAKTERISTIK: } \\
\text { 1. Perusahaan } \\
\text { de-ngan } \\
\text { banyak peme- } \\
\text { gang saham, } \\
\text { namun masih } \\
\text { ada kepe- } \\
\text { milikan } \\
\text { mayoritas. } \\
\text { Fungsi } \\
\text { Prinsipal dan } \\
\text { Agen mulai } \\
\text { terpisah. } \\
\text { Meskipun } \\
\text { pemi-lik } \\
\text { mayoritas } \\
\text { masih } \\
\text { memiliki } \\
\text { otoritas yang } \\
\text { besar, kepen- } \\
\text { tingan } \\
\text { pemegang } \\
\text { saham } \\
\text { minoritas } \\
\text { sudah } \\
\text { diperhatikan }\end{array}$ & $\begin{array}{l}\text { KARAKTERISTIK: } \\
\text { 1. Perusahaan } \\
\text { dengan banyak } \\
\text { pemegang sa- } \\
\text { ham, dan tidak ada } \\
\text { ke-pemilikan } \\
\text { mayoritas. } \\
\text { 2. Sulit untuk meng- } \\
\text { identifikasi 'the true } \\
\text { principal'. } \\
\text { 3. Prinsipal umumnya } \\
\text { tidak atau kurang } \\
\text { memahami bisnis. } \\
\text { Agen memiliki pe- } \\
\text { ngaruh yang besar } \\
\text { dalam } \\
\text { menjalankan } \\
\text { perusahaan. } \\
\text { Terjadi ketidakse- } \\
\text { imbangan } \\
\text { kepentingan } \\
\text { (conflict of interest) } \\
\text { IMPLIKASI: } \\
\text { Aspek } \\
\text { Corpo-rate } \\
\text { Governance }\end{array}$ \\
\hline
\end{tabular}




\begin{tabular}{|l|l|l|}
\hline & IMPLIKASI: & SANGAT \\
& Aspek Good & diperlukan \\
& Cor-porate & \\
Governance & \\
& MULAI & \\
& diperlukan & \\
\hline
\end{tabular}

Sumber : Arifin, Drs. M.Com (2005)

Shareholding theory mangatakan bahwa perusahaan didirikan dan dijalankan untuk tujuan memaksimumkan kesejahteraan pemilik/pemegang saham sebagai akibat dari investasi yang dilakukannya. Shareholding theory ini sering disebut sebagai teori korporasi klasik yang sudah diperkenalkan oleh Adam Smith pada tahun 1776. Definisi CG yang berdasar pada shareholding theory diberikan oleh Monks dan Minow (1995) yaitu hubungan berbagai partisipan (pemilik/investor dan manajemen) dalam menentukan arah dan kinerja korporasi. Definisi lain diajukan oleh Shleifer dan Vishny (1997) yang menyebutkan bahwa $C G$ sebagai cara atau mekanisme untuk meyakinkan para pemilik modal dalam memperoleh hasil (return) yang sesuai dengan investasi yang ditanamkan 
Stakeholding theory, diperkenalkan oleh Freeman (1984), menyatakan bahwa perusahaan adalah organ yang berhubungan dengan pihak lain yang berkepentingan, baik yang ada di dalam maupun di luar perusahaan. Definisi stakeholder ini termasuk karyawan, pelanggan, kreditur, suplier, dan masyarakat sekitar dimana perusahaan tersebut beroperasi. Adapun definisi Good Corporate Governance dari Cadbury Committee yang berdasar pada teori stakeholder adalah sebagai berikut :

"A set of rules that define the relationship between shareholders, managers, creditors, the government, employees and internal and external stakeholders in respect to their rights and responsibilities".

(Seperangkat aturan yang mengatur hubungan antara para pemegang saham, manajer, kreditur, pemerintah, karyawan, dan pihak-pihak yang berkepentingan lainnya baik internal maupun eksternal lainnya yang berkaitan dengan hak-hak dan kewajiban mereka). 
Beberapa institusi Indonesia mengajukan definisi CG, antara lain oleh FCGI (Forum for Corporate Governance in Indonesia) tahun 2000 yang mendefinisikan CG sama seperti Cadbury Committee, sedangkan The Indonesian Institute for Corporate Governance atau IICG (2000) mendefinisikan CG sebagai proses dan struktur yang diterapkan dalam menjalankan perusahaan, dengan tujuan utama meningkatkan nilai pemegang saham dalam jangka panjang, dengan tetap memperhatikan kepentingan stakeholder yang lain.

Pengertian lain CG menurut Surat Keputusan Menteri Negara/Kepala Badan Penanaman Modal dan Pembinaan BUMN No. 23/M PM/BUMN/2000 tentang Pengembangan Praktik GCG dalam Perusahaan Perseroan (PERSERO), Good Corporate Governance adalah prinsip korporasi yang sehat yang perlu diterapkan dalam pengelolaan perusahaan yang dilaksanakan semata-mata demi menjaga kepentingan perusahaan dalam rangka mencapai maksud dan tujuan perusahaan 
Teori keagenan (agency theory) merupakan dasar untuk dapat memahami corporate governance secara keseluruhan. Menurut Jensen dan Meckling (1976), dinyatakan bahwa hubungan keagenan adalah sebuah kontrak atau perjanjian antara manager sebagai agent dan investor sebagai principal yang terkadang menimbulkan asimetri informasi dari manager kepada investor sehingga menimmbulkan adanya biaya keagenan (agency cost). Menurut penelitian Eisenhardt (1989), dinyatakan bahwa teori keagenan (agency theory) berdasarkan pada tiga sifat dasar manusia, yaitu:

1. Manusia pada umumnya mementingkan diri sendiri (self interest)

2. Manusia memiliki daya pikir terbatas tentang persepsi masa depan (bounded rationality)

3. Manusia selalu menghindari resiko (risk averse)

Berdasarkan tiga sifat dasar manusia tersebut, manager akan bertindak opportunistic, yaitu mengutamakan kepentingan pribadinya 
(Haris, 2004). Menurut penelitian Verrechia (2001), disimpulkan bahwa ada tiga solusi untuk menghadapi timbulnya teori keagenan (agency theory), diantaranya:

1. Kegiatan berdasar pada kebijakan (discretionary) yang dibuat oleh manager (agent) untuk menyelesaikan permasalahan teori keagenan, manajer melakukan cara untuk menyelesaikan agency problem dengan memberikan berbagai pengungkapan kepada investor (principal). Hal ini dilakukan untuk mengurangi biaya keagenan (agency cost) dengan cara mengawasi atau memonitor perilaku manajemen (management behaviour).

2. Aktivitas asosiasi yang dilakukan oleh investor untuk mengurangi biaya keagenan (agency cost).

3. Aktivitas efisiensi yang terjadi secara alamiah dalam kompetisi pasar saham.

Dalam prakteknya, aktivitas-aktivitas tersebut dilakukan oleh perusahaan untuk 
menstimulus sehingga dapat mengurangi biaya keagenan (agency cost).

Corporate governance merupakan konsep yang berfungsi sebagai alat untuk meyakinkan para investor bahwa mereka akan menerima return yang besar atas dana yang telah diinvestasikan (Ujiyantho dan Pramuka, 2007). Sehingga dengan adanya konsep corporate governance diharapkan dapat mengurangi timbulnya konflik antara manajemen perusahaan dengan para investor, sehingga dapat mengurangi timbulnya biaya keagenan (agency cost) sebagai akibat dari adanya konflik.

Implementasi dari good corporate governance dalam manajemen perusahaan dapat dilihat dari kemampuan perusahaan dalam mengimplementasikan konsep ini. Menurut Institute of Corporate Governance (IICG) dan Forum for Corporate Governance in Indonesia (FCGI), ada empat prinsip dari implementasi corporate governance:

1. Kewajaran (Fairness) 
Menjamin hak-hak para pemegang saham mayoritas, minoritas dan para pemegang saham asing serta menjamin terlaksananya komitmen dengan para investor.

2. Transparansi (Transparancy)

Mewajibkan adanya suatu informasi yang terbuka, tepat waktu dan jelas serta dapat dibandingkan tentang berbagai hal, misalnya: kondisi keuangan perusahaan, pengelolaan perusahaan, kepemilikan perusahaan dan sebagainya.

3. Akuntabilitas (Accountability)

Menjelaskan peran dan tanggung jawab serta mendukung usaha untuk menjamin keseimbangan kepentingan antara pemegang saham dan manajemen perusahaan.

4. Pertanggungjawaban (Responsibility)

Memastikan peraturan dan ketentuan yang berlaku telah dipatuhi sebagai cerminan dipatuhinya nilai-nilai sosial. 
Menurut OECD, ada 5 prinsip dalam pengimplementasian corporate governance, diantaranya adalah:

1. Pemenuhan hak-hak para pemegang saham.

2. Perlakuan yang sama terhadap para pemegang saham sehingga tidak membedakan antara pemegang saham mayoritas dan minoritas.

3. Peranan semua pihak yang berkepentingan (stakeholder) dalam pengimplementasian corporate governance.

4. Transparansi dan penjelasan terkait kinerja perusahaan secara jelas dan akurat bagi para stakeholder perusahaan.

5. Peranan dewan dalam melaksanakan fungsi pengawasan dan pengelolaan perusahaan.

Menurut penelitian Melvill dalam Sunarto (2003), konsep corporate governance dapat tercapai secara efektif apabila manajemen perusahaan melakukan beberapa tindakan, yaitu:

1. Mengidentifikasi dengan tepat, mengevaluasi, dan mengatur resiko serta kesempatan. 
2. Meninjau kembali kebijakan yang dibuat oleh perusahaan dan menjelaskan tujuan perusahaan secara keseluruhan.

3. Melaksanakan standart dan etika yang telah ditetapkan.

4. Memandang dewan-dewan perusahaan sebagai seorang ahli di bidangnya.

Menurut Hananto (2004) dalam Octaviani (2009), ada beberapa manfaat dalam penerapan good corporate governance, diantaranya:

1. Mengurangi agency cost.

2. Mengurangi biaya modal.

3. Meningkatkan nilai saham perusahaan.

4. Meningkatkan citra perusahaan tersebut dalam jangka panjang.

5. Menciptakan dukungan dari para stakeholder dalam lingkungan perusahaan terhadap strategi dan kebijakan dalam perusahaan tersebut.

Manajemen perusahaan merupakan komponen dari stakeholder yang berpengaruh terhadap keberhasilan penerapan good corporate 
governance yang kemudian akan mempengaruhi nilai perusahaan secara keseluruhan. Struktur kepemilikan manajerial merupakan salah satu komponen penting dari corporate governance. Hubungan antara kepemilikan (ownership) dan manajemen adalah untuk menjadikan manajemen yang profesional dan mendapat laba yang maksimal dengan efisiensi biaya (FCGI, 2006). Selain adanya struktur kepemilikan manajerial, adanya organ-organ perusahaan (dewan direksi maupun dewan komisaris) menjadi bukti dari implementasi corporate governance dalam tataran minimal (Surya dan Yustiavanadana, 2006) 


\section{BAB IV}

\section{PRINSIP-PRINSIP CORPORATE}

\section{GOVERNANCE}

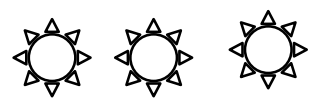

\section{A. Prinsip-prinsip Corporate Governance}

Organisation for Economic Co-Operation and Development (OECD) menyatakan bahwa prinsip-prinsip corporate governance meliputi :

\section{Akuntabilitas (accountability)}

Prinsip ini memuat kewenangankewenangan yang harus dimiliki oleh dewan komisaris dan direksi beserta kewajibankewajibannya kepada pemegang saham dan stakeholders lainnya. Dewan direksi bertanggung jawab atas keberhasilan pengelolaan perusahaan dalam rangka mencapai tujuan yang telah ditetapkan oleh pemegang saham. Komisaris bertanggung jawab atas keberhasilan pengawasan 
dan wajib memberikan nasehat kepada direksi atas pengelolaan perusahaan sehingga tujuan perusahaan dapat tercapai. Pemegang saham bertanggung jawab atas keberhasilan pembinaan dalam rangka pengelolaan perusahaan.

\section{Pertanggung-jawaban (responsibility)}

Prinsip ini menekankan pada adanya system yang jelas untuk mengatur mekanisme pertanggungjawaban perusahaan kepada pemegang saham dan pihak-pihak lain yang berkepentingan. Hal tersebut untuk merealisasikan tujuan yang hendak dicapai dalam good corporate governance yaitu mengakomodasikan kepentingan pihak-pihak yang berkaitan dengan perusahaan seperti masyarakat, pemerintah, asosiasi bisnis dan sebagainya. Prinsip ini menuntut perusahaan maupun pimpinan dan manajer perusahaan melakukan kegiatannya secara bertanggung jawab.

\section{Keterbukaan (transparency)}


Dalam prinsip ini, informasi harus diungkapkan secara tepat waktu dan akurat. Informasi yang diungkapkan antara lain keadaan keuangan, kinerja keuangan, kepemilikan dan pengelolaan keuangan perusahaan. Audit yang dilakukan atas informasi dilakukan secara independent. Keterbukaan dilakukan agar pemegang saham dan orang lain mengetahui keadaan perusahaan sehingga nilai pemegang saham dapat ditingkatkan.

\section{Kewajaran (fairness)}

Prinsip ini menekankan pada jaminan perlindungan hak-hak para pemegang saham. Seluruh pemangku kepentingan harus memiliki kesempatan untuk mendapatkan perlakuan yang adil dari perusahaan. Pemberlakuan prinsip ini di perusahaan akan melarang praktek-praktek tercela yang dilakukan oleh orang dalam yang merugikan pihak lain. Setiap anggota direksi harus melakukan keterbukaan jika menemukan transaksi-transaksi yang mengandung benturan kepentingan. 


\section{B. Sistem Penilaian Pelaksanaan Good Corporate Governance}

Penilaian terhadap pelaksanaan good corporate governance di Indonesia dilakukan oleh lembaga independen yaitu: Forum for Corporate Governance in Indonesia (FCGI). Penilaian dilakukan dengan menggunakan kuesioner yang dijawab oleh pihak manajemen perusahaan. Aspek yang dinilai meliputi Hak-hak Pemegang Saham, Kebijakan Corporate Governance, Praktek-praktek Corporate Governance, Pengungkapan, dan Fungsi Audit. Penentuan skor pelaksanaan dilakukan melalui metode rata-rata tertimbang, dengan bobot masing-masing aspek sebagai berikut:

1) Hak-hak Pemegang Saham (20\%).

2) Kebijakan Corporate Governance (15\%).

3) Praktek-praktek Corporate Governance (30\%).

4) Pengungkapan (Disclosure) (20\%) dan

5) Fungsi Audit (15\%). 


\section{1) Hak-hak Pemegang Saham}

Dalam Hak-hak Pemegang Saham, penilaian dilakukan terhadap apakah perusahaan telah:

a. Melaksanakan RUPS tahunan dalam jangka waktu 6 bulan sesudah akhir tahun buku sesuai dengan pasal 65 ayat 2 Undangundang Perseroan Terbatas.

b. Menyampaikan kepada Pemegang Saham pemberitahuan mengenai RUPS tahunan minimal 28 hari sebelum pelaksanaan RUPS tersebut

c. Memberikan dorongan kepada para Pemegang Saham untuk menghadiri RUPS dan menggunakan hak suara-nya.

d. Memberikan kesempatan yang memadai bagi Pemegang Saham untuk mengajukan pertanyaan pada RUPS.

e. Dan seterusnya.

Selanjutnya diberikan penilaian, misalnya nilai 5 untuk setiap jawaban "ya" dan 0 untuk tiap jawaban "tidak". Jadi misalkan dari 10 pertanyaan 
di bidang Hak-hak Pemegang Saham tersebut peru-sahaan menjawab "ya" sebanyak 6 kali dan menjawab "tidak" sebanyak 4 kali maka dalam bidang tersebut perusahaan akan memperoleh skor:

$(6 \times 5)+(4 \times 0)=30$ (dari nilai maksimum 50 atau $10 \times 5)$

\section{2) Kebijakan Good Corporate Governance}

Bidang Kebijakan Good Corporate

Governance, perusahaan dapat menilai sendiri apakah pihaknya telah:

a. Memiliki Kode atau Pedoman Good Corporate Gover-nance secara tertulis, yang secara jelas menjabar-kan hak-hak Pemegang Saham, tugas dan tanggung jawab Direksi dan Komisaris.

b. Menyediakan akses bagi masyarakat untuk mengetahui kebijakan perusahaan mengenai investor.

c. Menentukan organisasi/orang yang bertanggung jawab (misalnya Komisaris) 
untuk memastikan bahwa perusahaan mentaati kode Good Corporate Governance.

d. Memiliki Code of Conduct/Ethics bagi karyawannya.

e. Aturan perilaku tersebut dikomunikasikan dan diimplementasikan dengan baik.

\section{3) Praktek-praktek Good Corporate}

\section{Governance}

Dalam bidang Praktek Good Corporate

Governance, dapat diteliti apakah di dalam perusahaan:

a. Direksi mengadakan pertemuan berkala secara teratur dengan Komisaris.

b. Terdapat rencana strategis dan rencana usaha yang memberikan arahan bagi Direksi dan Komisaris dalam menjalankan tugas dan fungsinya.

c. Direksi dan Komisaris mendapatkan pelatihan atau mempunyai latar belakang yang memadai untuk menun-jang pelaksanaan pekerjaaanya. 
d. Para anggota Komisaris maupun Direksi telah bebas dari benturan kepentingan (conflict of interests).

e. Ada sistem penilaian kinerja untuk Direksi maupun Komisaris.

\section{4) Pengungkapan (Disclosure)}

Sementara itu dalam bidang Pengungkapan (Disclosure), dapat dinilai apakah perusahaan telah:

a. Menyediakan akses yang sama bagi Pemegang Saham dan analis keuangan.

b. Memberikan penjelasan yang memadai mengenai risiko usaha.

c. Mengungkapkan remunerasi/kompensasi Direksi dan Komi-saris secara memadai.

d. Mengungkapkan transaksi dengan pihakpihak yang mempunyai hubungan istimewa.

e. Menyajikan hasil kinerja keuangannya dan analisa mana-jemen melalui internet.

\section{5) Fungsi Audit}


Dalam bidang Audit, dapat dinilai apakah perusahaan telah:

a. Mempunyai internal audit yang efektif.

b. Diaudit oleh akuntan publik yang independen.

c. Memiliki komite audit yang efektif.

d. Menciptakan komunikasi yang efektif antara internal audit, external audit dan komite audit.

Selanjutnya, seperti halnya pada bidang hak pemegang saham, pada bidang-bidang lainnya pun diberikan skor (misalnya untuk setiap jawaban "ya" diberikan nilai 5 sedangkan untuk setiap jawaban "tidak"diberikan nilai "0"). Dari hasil pemberian skor tersebut, misalnya didapat skor untuk:

1. Hak-hak Pemegang Saham $=30$ (dari nilai maks 50).

2. Kebijakan Corporate Governance $=45$ (dari nilai maks 60).

3. Praktik-praktik Corporate Governance $=60$ (dari nilai maks 80 ). 
4. Pengungkapan (Disclosure) $=25$ (dari nilai maks 40) dan

5. Audit $=30$ (dari nilai maks 40).

Selanjutnya untuk menentukan skor keseluruhan digunakan metode rata-rata tertimbang (dengan pembobotan seperti dijelaskan di awal tulisan ini). Dengan demikian skor keseluruhan untuk perusahaan tersebut adalah:

$\{(30 / 50 \times 20 \%)+(45 / 60 \times 15 \%)+(60 / 80 \times 30 \%)+$ $(25 / 40 \times 20 \%)+(30 / 40 \times 15 \%)\}=69.5 \%$ atau skor 69.5 dari skor tertinggi 100 .

Keempat komponen tersebut penting karena penerapan prinsip GCG secara konsisten terbukti dapat meningkatkan kualitas laporan keuangan (Beasly et al., 1996). Chtourou et al. (2001) juga mencatat prinsip GCG yang diterapkan dengan konsisten dapat menjadi penghambat (constrain) aktivitas rekayasa kinerja yang mengakibatkan laporan keuangan tidak menggambarkan nilai fundamental perusahaan. 


\section{BAB Y}

\section{STRUKTUR CORPORATE GOVERNANCE}

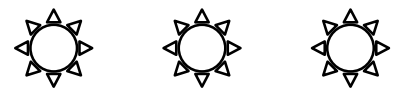

Struktur didefinisikan sebagai satu cara bagaimana aktivitas dalam organisasi dibagi, diorganisir, dan dikoordanasi (Stoner, Freeman, dan Gilbert, 1995). Struktur governance, dapat diartikan sebagai suatu kerangka dalam organisasi untuk menerapkan berbagai prinsip governance sehingga prinsip tersebut dapat dibagi, dijalankan serta dikendalikan. Secara spesifik, struktur governance harus didesain untuk mendukung jalannya aktivitas organisasi secara bertanggungjawab dan terkendali.

\section{A. Model Anglo-Saxon}

Pada dasarnya struktur governance diatur oleh Undang-undang sebagai dasar legalitas 
berdirinya sebuah entitas. Misalnya dalam model Anglo-Saxon, struktur governance akan terdiri dari RUPS (Rapat Umum Pemegang Saham), Board of Directors (representasi dari para pemegang saham/pemilik), serta Executive managers (manajemen yang akan menjalankan aktivitas). Model Anglo-Saxon ini disebut dengan Singleboard system yaitu struktur CG yang tidak memisahkan keanggotaan dewan komisaris dan dewan direksi. Dalam sistem ini anggota dewan komisaris juga merangkap anggota dewan direksi dan kedua dewan ini disebut sebagai board of directors. Bagan 1 di bawah ini adalah skema yang menunjukkan struktur single-board system.

\section{B. Model Continental Europe}

Sedangkan untuk model Continental Europe, struktur governance terdiri dari RUPS, Dewan Komisaris, Dewan Direktur, dan Manajer Eksekutif (manajemen). Struktur semacam ini disebut Twoboard system, yaitu struktur CG yang dengan tegas 
memisahkan keanggotaan dewan, yakni antara keanggotaan dewan komisaris sebagai pengawas dan dewan direksi sebagai eksekutif perusahaan.

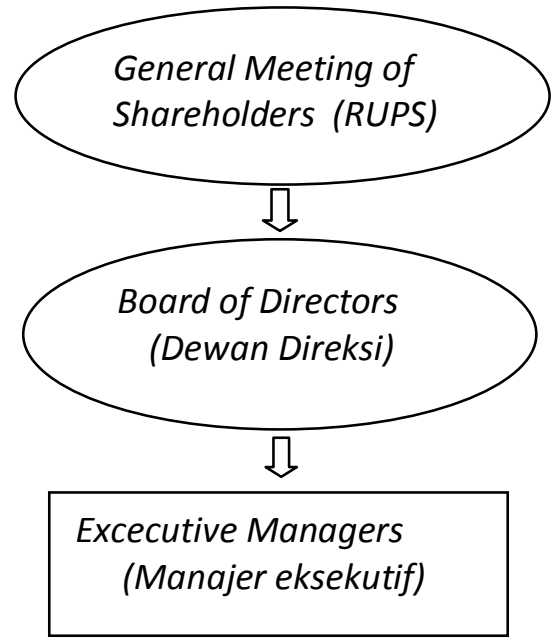

Gambar 5.1. Struktur Corporate Governance Single-Board System (Anglo-Saxon Model)

Sumber : Tjager dkk (2003) dan Syakhroza (2005).

Dalam model two-board system, RUPS (Rapat Umum Pemegang Saham) merupakan struktur tertinggi yang mengangkat dan memberhentikan dewan komisaris yang mewakili para pemegang saham untuk melakukan kontrol terhadap manajemen. Dewan komisaris 
membawahi langsung dewan direksi dan mempunyai kewenangan untuk mengangkat dan memberhentikan dewan direksi serta melakukan tugas pengawasan terhadap kegiatan direksi dalam menjalankan perusahaan. Posisi dewan komisaris dalam model ini relatif kuat terhadap direksi sehingga fungsi pengendalian/kontrol terhadap kegiatan manajemen dapat berjalan dengan efektif.

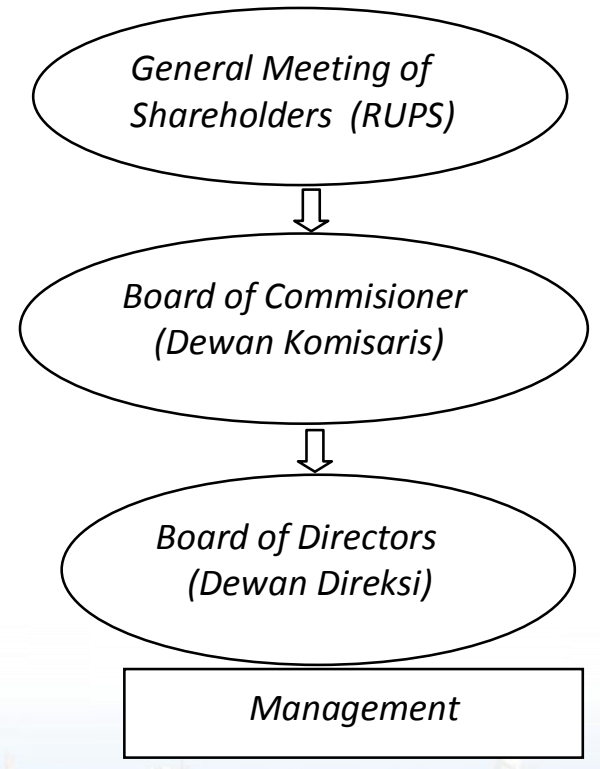

Gambar 2. 2. Struktur Governance Model DualBoard System (Continental Europe Model) Sumber : Tjager dkk (2003) dan Syakhroza (2005). 
Gambar 2.2. di bawah ini adalah skema yang menunjukkan struktur Corporate Governance model Continental Europe (Dual-Board System).

\section{Model Governance di Indonesia}

Perusahaan-perusahaan di Indonesia pada umumnya berbasis two-board system atau two-tier board system seperti kebanyakan perusahaan di Eropa (model Continental Europe). Hanya ada perbedaan dalam kedudukan dewan komisaris yang tidak langsung membawahi dewan direksi. Hal ini sesuai dengan aturan yang ada dalam Undang-Undang Perseroan Terbatas tahun 1995 yang menyatakan bahwa anggota dewan direksi diangkat dan diberhentikan oleh RUPS (pasal 80 ayat 1 dan pasal 91 ayat 1), demikian juga anggota dewan komisaris diangkat dan diberhentikan oleh RUPS (pasal 95 ayat 1 dan pasal 101 ayat 1). Dengan adanya struktur yang demikian, maka baik dewan komisaris maupun dewan direksi bertanggungjawab terhadap RUPS (kedudukannya 
sejajar). Bagan 3 di bawah ini menunjukan struktur CG di Indonesia.

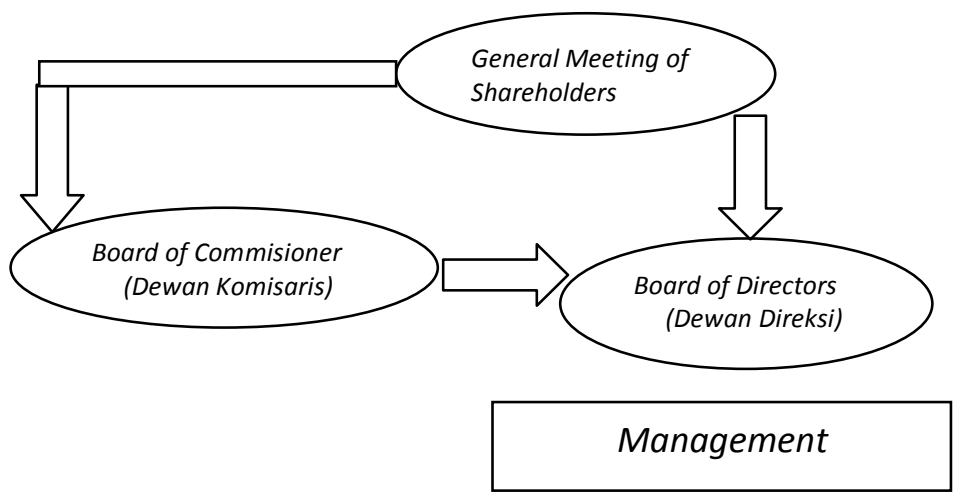

Gambar 2. 3. Struktur Corporate Governance di Indonesia (Dual-Board System)

Sumber : Tjager dkk (2003) dan Syakhroza (2005).

Dengan melihat posisi yang sejajar antara dewan komisaris dan dewan direksi (manajemen) pada perusahaan-perusahaan di Indonesia, mengakibatkan kedudukan dewan komisaris di Indonesia tidak sekuat seperti dewan komisaris di Continental Europe karena dewan komisaris tidak berwenang mengangkat dan memberhentikan dewan direksi. Dewan direksi tidak harus bertanggung jawab terhadap dewan komisaris. Bila 
ditinjau dari perspektif good governance, kedududukan yang sejajar ini dapat mengakibatkan pelaksanaan fungsi pengendalian (control) berjalan kurang efektif karena bisa saja dewan komisaris dianggap oleh dewan direksi sebagai partner kerja, bukan sebagai pengawas kerja dewan direksi. Hal ini bisa menjadi salah satu hambatan untuk melaksanakan GCG pada perusahaan-perusahaan di Indonesia. Saran yang dapat diberikan adalah perlu ditinjau kembali Undang-undang Perseroan Terbatas, khususnya tentang pengaturan kembali adanya kedudukan yang sejajar antara dewan komisaris dan dewan direksi.

Mekanisme corporate governance merupakan suatu aturan main, prosedur dan hubungan yang jelas antara pihak yang mengambil keputusan dengan pihak yang melakukan kontrol/pengawasan terhadap keputusan tersebut. Mekanisme governance diarahkan untuk menjamin dan mengawasi berjalannya sistem governance dalam sebuah organisasi (Walsh dan Seward, 1990). 
Walsh dan Seward (1990) menyatakan bahwa terdapat 2 mekanisme untuk membantu menyamakan perbedaan kepentingan antara pemegang saham dan manajer dalam rangka penerapan GCG, yaitu: (1) mekanisme pengendalian internal perusahaan, dan (2) mekanisme pengendalian eksternal berdasarkan pasar.

Mekanisme pengendalian internal adalah pengendalian perusahaan yang dilakukan dengan membuat seperangkat aturan yang mengatur tentang mekanisme bagi hasil, baik yang berupa keuntungan, return maupun risiko-risiko yang disetujui oleh prinsipal dan agen. Salah satu pilihan mekanisme pengendalian internal untuk menyamakan kepentingan pemegang saham dan manajer adalah kontrak insentif jangka panjang (Walsh dan Seward, 1990; Jensen, 1993). Kontrak jangka panjang ini dilakukan dengan memberikan insentif pada menajer apabila nilai perusahaan atau kemakmuran pemegang saham meningkat, salah satunya dengan cara memberi kepemilikan saham 
kepada manajer (Jensen dan Meckling, 1976; Fama, 1980). Dengan demikian, manajer akan termotivasi untuk meningkatkan nilai perusahaan atau meningkatkan kemakmuran pemegang saham karena hal tersebut juga akan meningkatkan kekayaan manajer sendiri.

Mekanisme pengendalian eksternal adalah pengendalian perusahaan yang dilakukan oleh pasar. Menurut teori pasar untuk pengendalian perusahaan (market for corporate control), pada saat diketahui bahwa manajemen berperilaku menguntungkan diri sendiri, kinerja perusahaan akan menurun yang direfleksikan oleh nilai saham perusahaan. Pada kondisi tersebut, kelompok menajer lain akan menggantikan manajer yang sedang memegang jabatan. Dengan demikian bekerjanya market for corporate control bisa menghambat tindakan menguntungkan diri manajer sendiri (Jensen dan Meckling, 1976).

Mekanisme pengendalian lain yang secara luas digunakan dan diharapkan dapat menyelaraskan tujuan prinsipal dan agen adalah 
mekanisme melalui pelaporan keuangan. Melalui laporan keuangan yang merupakan tanggungjawab manajer, pemilik dapat mengukur, menilai, sekaligus dapat mengawasi kinerja manajer untuk mengetahui sejauh mana menajer telah bertindak untuk meningkatkan kesejahteraan pemilik. Selain itu pemilik dapat memberikan kompensasi kepada manajer berdasarkan laporan keuangan. Laporan keuangan yang dibuat dengan berdasarkan angkaangka akuntansi diharapkan berperan besar dalam meminimalkan konflik antara berbagai pihak yang berkepentingan dalam perusahaan (Jensen dan Meckling, 1976; Watts dan Zimerman, 1986).

Dalam hubungannya dengan jenis informasi yang disajikan dalam laporan keuangan perusahaan, terdapat dua jenis sifat informasi yang diungkapkan. Penmann (1988) membagi sifat informasi yang diungkapkan menjadi mandatory disclosure dan voluntary disclosure.

1) Informasi yang bersifat mandatory disclosure merupakan informasi yang harus diungkapkan dalam laporan keuangan 
karena memang diwajibkan oleh peraturan atau undang-undang.

2) Sedangkan voluntary disclosure merupakan jenis informasi yang secara sukarela diungkapkan di dalam laporan keuangan yang bertujuan untuk menambah kegunaan informasi mengenai kekayaan dan hasil operasi suatu perusahaan kepada para pemakai laporan keuangannya.

Informasi yang bersifat voluntary disclosure ini berperan untuk melengkapi informasi yang bersifat mandatory disclosure yang diharapkan dapat meningkatkan kegunaan informasi dalam laporan keuangan.

Dari hasil penelitian terdahulu diperoleh hasil bahwa praktik disclosure ternyata sangat beragam antar negara. Chow dan Wong-Boren (1987) serta Meek dan Robert (1995) menyatakan bahwa di Meksiko informasi mengenai laba unit bisnis (profit by lines of business) adalah wajib diungkapkan (mandatory), tetapi di Swedia dan Perancis, informasi inibersifat voluntary. Sebaliknya, di 
Swedia dan Perancis informasi tentang tanggungjawab sosial (social responsibility) perusahaan wajib diungkapkan, tetapi di Meksiko informasi tersebut masih bersifat sukarela. Perbedaan ini disebabkan peraturan tentang disclosure yang berbeda antara negara yang satu dengan negara lainnya. Selain hal tersebut, keragaman informasi yang disajikan juga disebabkan oleh perbedaan karakteristik pasar, khususnya pasar modal antara negara maju dan negara yang masih berkembang. Penelitian Saudagaran dan Diga (1997) tentang karakteristik dan isu-isu kebijakan pelaporan keuangan antar berbagai pasar modal di negara maju dan berkembang menemukan hasil bahwa perbedaan tersebut didasari atas tiga kriteria yaitu :

1) availability of information (ketersediaan informasi)

2) reliability (keandalan), dan

3) comparability (daya banding).

Dalam hubungannya dengan faktor yang mempengaruhi disclosure dalam laporan 
keuangan, berbagai penelitian telah dilakukan, diantaranya oleh Firth (1989), Cooke (1992), dan Arifin (2001). Firth (1989) meneliti praktik voluntary disclosure perusahaan publik di Inggris. Dia menyatakan bahwa perusahaan yang tergolong perusahaan berskala kecil di Inggris memiliki kecenderungan untuk lebih meningkatkan voluntary disclosure dalam laporan keuangannya dengan tujuan agar dapat memperoleh sumber dana di pasar modal. Cooke (1992) meneliti laporan tahunan perusahaan publik di Jepang. Dia menemukan bahwa voluntary disclosure sangat dipengaruhi oleh besar (size) perusahaan. Perusahaan yang berskala besar secara signifikan mengungkapkan lebih banyak informasi daripada perusahaan yang berskala kecil. Di Indonesia, Arifin (2001) menemukan bahwa perusahaan yang berbasis asing (multinational firms) ternyata memiliki level of voluntary disclosure yang lebih tinggi daripada perusahaan domestik. Selain itu, Arifin (2001) juga menemukan bahwa dari 60 item informasi yang bersifat voluntary disclosure dari 
persepsi pemakai (users), 24 item memiliki derajat kepentingan yang tinggi, sedangkan dari persepsi penyaji atau manajemen (preparers) hanya sejumlah 12 item.

Agar penyelenggaraan corporate governance berjalan dengan baik (good corporate governance). Pemerintah mengeluarkan beberapa peraturan antara lain Bapepam dengan Surat Edaran No. SE-03/PM/2000 mensyaratkan bahwa setiap perusahaan go public di Indonesia wajib membentuk Komite Audit dengan anggota minimal 3 orang yang diketuai oleh satu orang komisaris independent perusahaan dan dua orang eksternal yang independent terhadap perusahaan. Selain independent, dalam SE tersebut juga mensyaratkan bahwa yang bersangkutan menguasai dan memiliki latar belakang akuntansi dan keuangan. Sementara bagi perusahaan BUMN/BUMD, sesuai dengan Keputusan Menteri Badan Usaha Milik Negara Nomor: 117/MMBU/2002 menyatakan bahwa: "Komisaris/Dewan Pengawas harus membentuk komite yang bekerja 
secara kolektif dan berfungsi membantu Komisaris/Dewan Pengawas dalam melaksanakan tugasnya, yaitu membantu Komisaris/ Dewan Pengawas dalam memastikan efektifitas sistem pengendalian intern, efektivitas pelaksanaan tugas auditor eksternal dan auditor internal" Kalbers \& Fogarty (1993) menyebutkan tiga faktor yang mempengaruhi keberhasilan komite audit dalam menjalankan tugasnya yaitu 1) kewenangan formal dan tertulis, 2) kerjasama manajemen dan 3) kualitas/kompetensi anggota komite audit. Selain itu, Effendi (2005) juga menambahkan masalah komunikasi dengan komisaris, direksi, auditor internal dan eksternal serta pihak lain sebagai aspek yang penting dalam keberhasilan kerja komite audit. Dengan kewenangan, independensi, kompetensi dan komunikasi melalui pertemuan yang rutin dengan pihak-pihak terkait, diharapkan fungsi dan peran dari komite audit lebih bisa berjalan dengan efektif sehingga dapat mengidentifikasi kemungkinan adanya praktek manajemen laba yang oportunistik. 
Kelley et al. (2005) menemukan bukti bahwa predicted component of abnormal current accruals yang berkaitan dengan komite audit (independensi dan aktivitas) berhubungan positif dengan arus kas perusahaan satu tahun ke depan. Penelitian ini memberikan bukti bahwa manajemen laba yang dilakukan perusahaan lebih bersifat efisien. Sedang penelitian di Indonesia oleh Siregar dan Utama (2005) serta Siregar P (2005) menunjukkan kecenderungan bahwa keberadaan komite audit ternyata tidak berpengaruh terhadap jenis manajemen laba perusahaan.

Price Waterhouse Coopers dalam Surya dan Yustiavandana (2006: 26) mendefinisikan bahwa corporate governance terkait dengan pengambilan keputusan yang efektif, dibangun melalui kultur organisasi, nilai-nilai, sistem, berbagai proses, kebijakan-kebijakan dan struktur organisasi, yang bertujuan untuk mencapai bisnis yang menguntungkan, efisien, dan efektif dalam mengelola risiko dan bertanggung jawab dengan memperhatikan kepentingan stakeholders. 
Dey Report (1994) dalam Siallagan dan machfoedz (2006) mengemukakan bahwa corporate governance yang efektif dalam jangka panjang dapat meningkatkan kinerja perusahaan dan menguntungkan para pemegang saham. Prinsip-prinsip good corporate governance dapat diimplmentasikan, apabila dalam struktur perseroan muncul suatu ide tentang "organ tambahan". Organ-organ tambahan tersebut diantaranya adalah: komisaris independen; direktur independen I direktur tidak terafilliasi; komite audit; dan sekretaris perusahaan (corporate secretary) (Surya dan Yustiavandana, 2006: 132).

Komite audit mempunyai peran yang sangat penting dan strategis dalam hal memelihara kredibilitas proses penyusunan laporan keuangan seperti halnya menjaga terciptanya sistem pengawasan perusahaan yang memadai serta dilaksanakannya good corporate governance. Apabila komite audit berfungsi secara efektif, maka control terhadap perusahaan akan lebih baik sehingga, Komposisi dewan komisaris berperan 
dalam menjalankan fungsi pengawasan, komposisi dewan dapat mempengaruhi pihak manajemen dalam menyusun laporan keuangan sehingga dapat diperoleh suatu laporan laba yang berkualitas (Boediono dalam Rachmawati dan Triatmoko, 2007). Adanya komisaris independen diharapkan dapat meningkatkan peran dewan komisaris sehingga tercipta good corporate governance di dalam perusahaan.

\section{Komponen Governance}

Dewan komisaris memegang peranan yang sangat penting dalam perusahaan, terutama dalam pelaksanaan Good Corporate Governance. Pembentukan dewan komisaris adalah salah satu mekanisme yang banyak dipakai untuk memonitor manajer. Penelitian Mace (1986) dalam Arifin (2005) menemukan bahwa pengawasan dewan komisaris terhadap manajemen pada umumnya tidak efektif. Proporsi dewan komisaris independen dalam sebuah perusahaan harus sedemikian rupa sehingga memungkinkan pengambilan keputusan 
yang efektif, tepat dan cepat serta dapat bertindak secara independen.

\section{1) Dewan Komisaris}

Dewan komisaris dalam suatu perusahaan lebih ditekankan pada fungsi monitoring dari implementasi kebijakan direksi. Peran komisaris ini diharapkan akan meminimalisir permasalahan agensi yang timbul antara dewan direksi dengan pemegang saham. Oleh karena itu dewan komisaris seharusnya dapat mengawasi kinerja dewan direksi sehingga kinerja yang dihasilkan sesuai dengan kepentingan pemegang saham. Dewan Komisaris memegang peranan penting dalam mengarahkan strategi dan mengawasi jalannya perusahaan serta memastikan bahwa para manajer benar-benar meningkatkan kinerja perusahaan sebagai bagian daripada pencapaian tujuan perusahaan. Yang terpenting dalam hal ini adalah kemandirian komisaris dalam pengertian bahwa Dewan Komisaris harus memiliki kemampuan untuk membahas permasalahan tanpa 
campur tangan manajemen, dilengkapi dengan informasi yang memadai untuk mengambil keputusan, dan berpartisipasi secara aktif dalam penetapan agenda dan strategi. Dewan Komisaris merupakan inti dari Corporate Governance yang ditugaskan untuk menjamin pelaksanaan strategi perusahaan, mengawasi manajemen dalam mengelola perusahaan, serta mewajibkan terlaksananya akuntabilitas Egon Zehnder International, 2000 hal.12-13).

Secara umum dewan komisaris ditugaskan dan diberi tanggung jawab atas pengawasan kualitas informasi yang terkandung dalam laporan keuangan. Hal ini penting mengingat adanya kepentingan dari manajemen untuk melakukan manajemen laba yang berdampak pada berkurangnya kepercayaan investor. Untuk mengatasinya dewan komisaris diperbolehkan untuk memiliki akses pada informasi perusahaan. Dewan komisaris tidak memiliki otoritas dalam perusahaan, maka dewan direksi bertanggung jawab untuk menyampaikan informasi terkait 
dengan perusahaan kepada dewan komisaris (NCCG, 2001). Selain mensupervisi dan memberi nasihat pada dewan direksi sesuai dengan UU No. 1 tahun 1995, fungsi dewan komisaris yang lain sesuai dengan yang dinyatakan dalam National Code for Good Corporate Governance 2001 adalah memastikan bahwa perusahaan telah melakukan tanggung jawab sosial dan mempertimbangkan kepentingan berbagai stakeholder perusahaan sebaik memonitor efektifitas pelaksanaan good corporate governance.

Pengaruh ukuran dewan komisaris terhadap kinerja perusahaan memiliki hasil yang beragam. Salah satu argumen menyatakan bahwa makin banyaknya personel yang menjadi dewan komisaris dapat berakibat pada makin buruknya kinerja yang dimiliki perusahaan (Yermack 1996, Eisenberg, Sundgren, dan Wells 1998, dan Jensen 1993). Hal tersebut dapat dijelaskan dengan adanya agency problems (masalah keagenan), yaitu dengan makin banyaknya anggota dewan komisaris maka badan ini akan mengalami kesulitan dalam menjalankan 
perannya, diantaranya kesulitan dalam berkomunikasi dan mengkoordinir kerja dari masing-masing anggota dewan itu sendiri, kesulitan dalam mengawasi dan mengendalikan tindakan dari manajemen, serta kesulitan dalam mengambil keputusan yang berguna bagi perusahaan (Yermack 1996, Jensen 1993).

Adanya kesulitan dalam perusahaan dengan anggota dewan komisaris yang banyak ini membuat sulitnya menjalankan tugas pengawasan terhadap manajemen perusahaan yang nantinya berdampak pula pada kinerja perusahaan yang semakin menurun (Yermack 1996, Eisenberg, Sundgren, dan Wells 1998). Terkait kinerja, ukuran dewan komisaris dapat memberi efek yang berkebalikan dengan efek terhadap kinerja. Kondisi ini tidak diikuti oleh beberapa penelitian. Yu (2006) menemukan bahwa ukuran dewan komisaris berpengaruh negatif secara signifikan terhadap manajemen laba yang diukur dengan menggunakan model Modified Jones untuk memperoleh nilai akrual kelolaannya. Hal ini 
menandakan bahwa makin sedikit dewan komisaris maka tindak kecurangan makin banyak karena sedikitnya dewan komisaris memungkinkan bagi organisasi tersebut untuk didominasi oleh pihak manajemen dalam menjalankan perannya. Chtourou, Bedard, dan Courteau (2001) juga menyatakan hal yang sama dengan Yu (2006). Sementara itu penelitian yang dilakukan oleh Zhou dan Chen (2004) menunjukkan bahwa ukuran dewan komisaris di bank komersial tidak berpengaruh terhadap earnings management yang diukur dengan menggunakan loan loss provisions. Pengujian tersebut menyimpulkan bahwa ukuran dewan komisaris secara signifikan berpengaruh dalam menghalangi tindak kecurangan dalam bentuk manajemen laba untuk perusahaan yang melakukan manajemen laba tinggi. Xie, Davidson, dan Dadalt (2003) juga menyatakan hal yang sama yaitu makin banyak dewan komisaris maka pembatasan atas tindak kecurangan dapat dilakukan lebih efektif. 
Hasil yang sejalan dengan Yermack 1996, Eisenberg, Sundgren, dan Wells 1998, dan Jensen 1993 diantaranya Beasley (1996) yang melaporkan bahwa pengaruh ukuran dewan komisaris terhadap kecurangan dalam pelaporan keuangan adalah positif secara signifikan. Untuk itu penelitian ini mendukung bahwa dewan komisaris yang lebih banyak kurang efektif dalam melakukan pengendalian terhadap manajemen. Penelitian Midiastuty dan Machfoedz (2003) menyatakan bahwa ukuran dewan komisaris berpengaruh secara signifikan terhadap indikasi manajemen laba yang dilakukan oleh pihak manajemen. Pengaruh tersebut ditunjukkan dengan tanda positif. Hal tersebut berarti makin besar ukuran dewan komisaris maka makin banyak kecurangan yang dilakukan oleh perusahaan, dan pada akhirnya akan menurunkan kinerja manajemen. Dari sini dapat disimpulkan bahwa jumlah komisaris yang lebih banyak lebih mampu mengurangi indikasi kinerja manajemen daripada jumlah komisaris yang sedikit. 
Jensen (1993) dan Lipton dan Lorsch (1992) dalam Beiner, Drobetz, Schmid dan Zimmermann (2003) merupakan yang pertama menyimpulkan bahwa ukuran dewan komisaris merupakan bagian dari mekanisme corporate governance. Hal ini diperkuat oleh pendapat Allen dan Gale (2000) dalam Beiner et al. (2003) yang menegaskan bahwa dewan komisaris merupakan mekanisme governance yang penting

\section{2) Dewan Direksi}

Dengan adanya pemisahan peran antara pemegang saham sebagai prinsipal dengan manajer sebagai agennya, maka manajer pada akhirnya akan memiliki hak pengendalian yang signifikan dalam hal bagaimana mereka mengalokasikan dana investor (Jensen \& Meckling, 1976; Shleifer \& Vishny, 1997). Selain itu Mizruchi (1983 dalam Midiastuti dan Mackfudz (2003)) juga menjelaskan bahwa dewan merupakan pusat dari pengendalian dalam perusahaan, dan dewan ini merupakan penanggung jawab utama dalam 
tingkat kesehatan dan keberhasilan perusahaan secara jangka panjang (Louden, 1982 dalam Midiastuti dan Mackfudz (2003).

Dewan direksi dalam suatu perusahaan akan menentukan kebijakan yang akan diambil atau strategi perusahaan tersebut secara jangka pendek maupun jangka panjang. Pentingnya dewan (baik dewan direksi maupun dewan komisaris) tersebut kemudian menimbulkan pertanyaan baru, berapa banyak dewan yang dibutuhkan perusahaan? Apakah dengan semakin banyak dewan berarti perusahaan dapat meminimilisasi permasalahan agensi antara pemegang saham dengan direksi. Jumlah dewan yang besar menguntungkan perusahaan dari sudut pandang resources dependence (Alexander, Fernell, Halporn, 1993; Goodstein, Gautarn, Boeker, 1994; Mintzberg, 1983). Maksud dari pandangan resources dependence adalah bahwa perusahaan akan tergantung dengan dewannya untuk dapat mengelola sumber dayanya secara lebih baik. Pfeffer \& Salancik (1978) dalam 
Bugshan (2005) juga menjelaskan bahwa semakin besar kebutuhan akan hubungan eksternal yang semakin efektif, maka kebutuhan akan dewan dalam jumlah yang besar akan semakin tinggi. Sedangkan kerugian dari jumlah dewan yang besar berkaitan dengan dua hal, yaitu: meningkatnya permasalahan dalam hal komunikasi dan koordinasi dengan semakin meningkatnya jumlah dewan dan turunnya kemampuan dewan untuk mengendalikan manajemen, sehingga menimbulkan permasalahan agensi yang muncul dari pemisahan antara manajemen dan kontrol (Jensen, 1993; Yermack, 1996).

Penelitian sebelumnya menyatakan bahwa perusahaan yang memiliki ukuran dewan yang besar tidak bisa melakukan koordinasi, komunikasi, dan pengambilan keputusan yang lebih baik dibandingkan dengan perusahaan yang memiliki dewan yang kecil sehingga nilai perusahaan yang memiliki dewan yang banyak lebih rendah dibandingkan dengan perusahaan yang memiliki direksi lebih sedikit (Jensen, 1993; Lipton and 
Lorsch, 1992; Yermack, 1996). Dalton et al. (1999) menyatakan adanya hubungan positif antara ukuran dewan dengan kinerja perusahaan. Sedangkan Eisenberg et al. (1998) menyatakan bahwa ada hubungan yang negatif antara ukuran dewan dengan kinerja perusahaan, dengan meggunakan sampel perusahaan di Finlandia. Jadi, dewan merupakan salah satu mekanisme yang sangat penting dalam CG, dimana keberadaannya menentukan kinerja perusahaan. Bukti yang menyatakan efektifitas ukuran dewan masih berbaur. Dari hasil yang masih belum konklusif tersebut dapat dikatakan bahwa pengaruh ukuran direksi terhadap kinerja perusahaan akan tergantung dari karakteristik dari masing-masing perusahaan terkait. Kaitan tersebut terutama dengan karakteristik perusahaan secara keuangan

\section{3) Dewan Komisaris Independen}

Salah satu permasalahan dalam penerapan CG adalah adanya CEO yang memiliki kekuatan yang lebih besar dibandingkan dengan dewan komisaris. Padahal fungsi dari dewan komisaris ini 
adalah untuk mengawasi kinerja dari dewan direksi yang dipimpin oleh CEO tersebut. Efektivitas dewan komisaris dalam menyeimbangkan kekuatan CEO tersebut sangat dipengaruhi oleh tingkat indepedensi dari dewan komisaris tersebut (Lorsch, 1989; Mizruchi, 1983; Zahra \& Pearce, 1989).

Penelitian mengenai dampak dari independensi dewan komisaris terhadap kinerja perusahaan ternyata masih beragam. Ada penelitian yang menyatakan bahwa tingginya proporsi dewan luar berhubungan positif dengan kinerja perusahaan (Yermack, 1996; Daily \& Dalton, 1993; Strearns \& Mizruchi, 1993), bukan merupakan faktor dari kinerja perusahaan (Kesner \& Johnson, (1990) dalam Bugshan (2005), dan berhubungan negatif dengan kinerja (Baysinger, Kosnik \& Turk, 1991; Goodstein \& Boeker, 1991).

Konteks independensi ini menjadi semakin kompleks dalam perusahaan yang sedang mengalami kesulitan keuangan. Pfeffer \& Salancik (1978) menyatakan bahwa dengan semakin meningkatnya tekanan dari lingkungan perusahaan 
maka kebutuhan akan dukungan dari luar juga semakin meningkat. Selain itu, Daily \& Dalton (1994) menyatakan bahwa apabila ada resistensi dari CEO untuk menerapkan strategi yang agresif untuk mengatasi kinerja perusahaan yang terus menurun, maka adanya direksi dari luar akan mendorong pengambilan keputusan untuk melakukan perubahan. Hal ini disebabkan oleh kecenderungan bahwa semakin tinggi representasi dewan dalam (insider board) maka keterlibatan direksi dalam pengambilan keputusan yang strategis akan semakin rendah (Judge \& Zeithaml, 1992).

Penelitian mengenai keberadaan dewan komisaris telah dilakukan diantaranya Peasnell, Pope, dan Young (1998) meneliti efektifitas dewan komisaris dan komisaris independen terhadap manajemen laba yang terjadi di Inggris. Dengan menggunakan sampel penelitian yang terdiri dari 1178 perusahaan selama periode tahun 19931996, hasil penelitian ini menunjukkan bahwa keberadaan komisaris independen membatasi 
pihak manajemen untuk melakukan manajemen laba. Xie, Davidson, dan Dadalt (2003) meneliti peran dewan komisaris dengan latar belakang bidang keuangan dalam mencegah manajemen laba. Dari penelitian ini diketahui makin sering dewan komisaris bertemu maka akrual kelolaan perusahaan makin kecil. Hal ini ditunjukkan dengan koefisien negatif yang signifikan. Penelitian ini juga menunjukkan bahwa persentase dewan komisaris dari luar perusahaan yang independen berpengaruh negatif secara signifikan terhadap akrual kelolaan. Beasley (1996) menyarankan bahwa masuknya dewan komisaris yang berasal dari luar perusahaan meningkatkan efektivitas dewan tersebut dalam mengawasi manajemen untuk mencegah kecurangan laporan keuangan.

Penelitian terkait dengan keberadaan dewan komisaris di Indonesia juga banyak dilakukan. Veronica dan Utama (2005) meneliti pengaruh praktik corporate governance terhadap manajemen laba. Praktik corporate governance yang diteliti yaitu proporsi dewan komisaris independen. Hasil 
dari penelitian ini adalah kesimpulan bahwa proporsi dewan komisaris independen tidak terbukti berpengaruh terhadap manajemen laba yang dilakukan oleh perusahaan. Boediono (2005) meneliti apakah komposisi dewan komisaris berpengaruh terhadap manajemen laba. Hasil dari penelitian ini diketahui bahwa secara parsial pengaruh corporate governance dalam hal ini komposisi dewan komisaris tidak berpengaruh terhadap manajemen laba. Veronica dan Bachtiar (2004) menemukan bahwa variabel persentase dewan komisaris independen tidak berkorelasi secara signifikan terhadap akrual kelolaan, walau begitu interaksi antar variabel akrual kelolaan dan dewan komisaris independen menunjukkan koefisien positif yang signifikan terhadap return perusahaan. Hal tersebut dapat dijelaskan dengan makin tingginya persentase dewan komisaris independen maka akrual kelolaan makin berpengaruh terhadap return.

Fama dan Jensen (1983) menyatakan bahwa non-executive director (komisaris 
independen) dapat bertindak sebagai penengah dalam perselisihan yang terjadi diantara para manajer internal dan mengawasi kebijakan manajemen serta memberikan nasihat kepada manajemen. Komisaris independen merupakan posisi terbaik untuk melaksanakan fungsi monitoring agar tercipta perusahaan yang good corporate governance.

Hasil penelitian Dechow, Patricia, Sloan dan Sweeney (1996), Klein (2002), Peasnell, Pope dan Young (2001), Chtourou et al. (2001), Midiastuti dan Mackfudz (2003), dan Xie, Biao, Wallace dan Peter (2003) memberikan simpulan bahwa perusahaan yang memiliki proporsi anggota dewan komisaris yang berasal dari luar perusahaan atau outside director dapat mempengaruhi kinerja. Sehingga, jika anggota dewan komisaris dari luar meningkatkan tindakan pengawasan, hal ini juga akan berhubungan dengan makin rendahnya penggunaan discretionary accruals (Cornett et al., 2006). 


\section{4) Komite Audit}

Komite audit yang bertanggung jawab untuk mengawasi laporan keuangan, mengawasi audit eksternal, dan mengamati sistem pengendalian internal (termasuk audit internal) dapat mengurangi sifat opportunistic manajemen yang melakukan manajemen laba (earnings management) dengan cara mengawasi laporan keuangan dan melakukan pengawasan pada audit eksternal.

Penelitian mengenai komite audit ada yang mengindikasikan kurang efektifnya keberadaan komite audit sebagai salah satu praktek corporate governance di perusahaan-perusahaan yang terdaftar di BEJ. Mayangsari (2003) meneliti pengaruh keberadaan komite audit terhadap integritas laporan keuangan, disimpulkan bahwa keberadaan komite audit berhubungan negatif dengan integritas laporan keuangan. Sedangkan Nuryanah (2004) dalam Effendi (2005) menemukan bahwa komite audit tidak mempengaruhi nilai perusahaan secara signifikan. Namun Effendi (2005) menyimpulkan adanya peranan komite audit 
dalam meningkatkan kinerja perusahaan, terutama dari aspek pengendalian.

Klein (2002) memberikan bukti secara empiris bahwa perusahaan yang membentuk komite audit independen melaporkan laba dengan kandungan akrual diskresioner yang lebih kecil dibandingkan dengan perusahaan yang tidak membentuk komite audit independen. Kandungan discretionary accruals tersebut berkaitan dengan kualitas laba perusahaan. Price Waterhouse (1980) dalam Mc.Mullen (1996) menyatakan bahwa investor, analis dan regulator menganggap komite audit memberikan kontribusi dalam kualitas pelaporan keuangan. Komite audit meningkatkan integritas dan kredibilitas pelaporan keuangan melalui: (1) pengawasan atas proses pelaporan termasuk sistem pengendalian internal dan penggunaan prinsip akuntansi berterima umum, dan (2) mengawasi proses audit secara keseluruhan. Hasilnya mengindikasikan bahwa adanya komite audit memiliki konsekuensi pada laporan keuangan yaitu: (1) berkurangnya 
pengukuran akuntansi yang tidak tepat, (2) berkurangnya pengungkapan akuntansi yang tidak tepat dan (3) berkurangnya tindakan kecurangan manajemen dan tindakan illegal. 


\section{BAB. VI}

\section{PEDOMAN UMUM CORPORATE GOVERNANCE DI BEBERAPA NEGARA ASIA}

$\int_{4}^{\infty}$

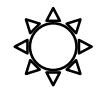

$\int_{5}^{50}$

A. Pedoman Corporate Governance di Indonesia

Pedoman Umum Good Corporate Governance di Indonesiakan disusun oleh Komite nasional Kebijakan Governance. Pedoman yang diterbitkan pada tahun 2006 ini merupakan revisi atas Pedoman Good Corporate Governance yang diterbitkan pada tahun 2001. Meskipun Pedoman Umum Good Corporate Governance Indonesia 2006 ini tidak memiliki kekuatan hukum yang mengikat, namun dapat menjadi rujukan bagi dunia usaha dalam menerapkan Good Corporate Governance. 


\section{Metode penerapan Pedoman Good Corporate \\ Governance}

Pelaksanaan Pedoman Umum Good Corporate

Governance oleh perusahaan-perusahaan di Indonesia baik perusahaan terbuka (Emiten/Perusahaan Publik) maupun perusahaan tertutup pada dasarnya bersifat comply and explain. Di mana perusahaan diharapkan menerapkan seluruh aspek Pedoman Good Corporate Governance ini. Apabila belum seluruh aspek pedoman ini dilaksanakan maka perusahaan harus mengungkapkan aspek yang belum dilaksanakan tersebut beserta alasannya dalam laporan tahunan. Namun demikian mengingat Pedoman ini hanya merupakan acuan sedangkan pelaksanaannya diharapkan diatur lebih lanjut oleh otoritas masing-masing industri maka penerapan ini bersifat voluntary dan tidak terdapat sanksi hukum apabila perusahaan tidak menerapkan pedoman ini.

Saat ini, Bapepam-LK sebagai otoritas pasar modal tidak mewajibkan Emiten dan Perusahaan Publik untuk menerapkan Pedoman ini, namun beberapa substansi yang terdapat dalam pedoman 
ini diadopsi oleh Bapepam-LK ke dalam peraturanperaturan Bapepam-LK yang sifatnya mandatory seperti kewajiban pembentukan komite audit dan keberadaan komisaris independen dalam perusahaan. Dengan cara demikian, Bapepam-LK dapat memberikan sanksi atas ketidakpatuhan terhadap peraturan tersebut. Lebih lanjut, Bapepam-LK juga mewajibkan Emiten dan Perusahaan Publik untuk mengungkapkan pelaksanaan tata kelola perusahaan dalam laporan tahunan seperti frekuensi rapat dewan komisaris dan direksi, frekuensi kehadiran anggota dewan komisaris dan direksi dalam rapat tersebut, frekuensi rapat dan kehadiran komite audit, pelaksanaan tugas dan pertanggungjawaban dewan komisaris dan direksi serta remunerasi dewan komisaris dan direksi.

2. Sanksi atas ketidakpatuhan terhadap Pedoman Good Corporate Governance

Mengingat Pedoman Umum Good Corporate Governance ini bersifat voluntary maka tidak 
terdapat sanksi dalam hal perusahaan tidak menerapkan pedoman tersebut.

\section{Ruang lingkup Pedoman Good Corporate}

\section{Governance}

Pedoman Umum Good Corporate Governance Indonesia memuat prinsip dasar dan pedoman pokok pelaksanaan Good Corporate Governance yang merupakan standar minimal yang mencakup:

a. Peran negara, dunia usaha dan masyarakat dalam menciptakan situasi kondusif untuk melaksanakan Good Corporate Governance

b. Asas-asas Good Corporate Governance yang meliputi transparansi, akuntabilitas, responsibilitas, independensi dan kewajaran dan kesetaraan

c. Etika Bisnis dan Pedoman Perilaku

d. Rapat Umum Pemegang Saham

e. Komposisi,persyaratan,pengangkatan/pemberhentian, tugas dan fungsi, komite penunjang dan pertanggungjawaban Dewan Komisaris 
f. Komposisi,persyaratan,pengangkatan/ pemberhentian, tugas dan fungsi, dan pertanggungjawaban Direksi

g. Hak dan tanggungjawab Pemegang saham

h. Pemangku kepentingan yang meliputi karyawan, mitra bisnis dan masyarakat serta pengguna produk atau jasa perusahaan

i. Pernyataan tentang penerapan Pedoman Good Corporate Governance

j. Pedoman Praktis Penerapan Good Corporate Governance

\section{Komposisi dan persyaratan Komisaris Independen}

Berdasarkan Pedoman Good Corporate
Governance, komposisi atau jumlah Komisaris Independen tidak ditentukan dalam jumlah tertentu namun demikian jumlah atau komposisi komisaris independen harus dapat menjamin agar mekanisme pengawasan berjalan secara efektif dan sesuai dengan peraturan perundang-undangan. Adapun kriteria yang ditetapkan yaitu salah satu dari Komisaris Independen 
harus mempunyai latar belakang akuntansi atau keuangan.

Meskipun Pedoman Good Corporate Governance tidak menentukan jumlah Komisaris Independen, dalam Peraturan Bapepam-LK, Emiten atau Perusahaan Publik wajib memiliki sekurang-kurangnya satu orang komisaris independen sedangkan Bursa Efek Indonesia mewajibkan sekurang-kurangnya $30 \%$ dari Dewan Komisaris adalah Komisaris Independen.

Kriteria Komisaris Independen secara rinci diatur dalam peraturan Bapepam-LK yaitu :

a. Berasal dari luar Emiten atau Perusahaan Publik

b. Tidak mempunyai saham Emiten atau Perusahaan Publik baik langsung maupun tidak langsung

c. Tidak mempunyai hubungan Afiliasi dengan Komisaris, Direksi dan Pemegang saham Utama Emiten atau Perusahaan Publik

d. Tidak mempunyai hubungan usaha dengan Emiten atau Perusahaan Publik baik langsung maupun tidak langsung 


\section{Komposisi/jumlah Direksi}

Dalam Pedoman Good Corporate Governance tidak dinyatakan secara kuantitatif jumlah atau komposisi dari direksi, namun demikian jumlah anggota direksi harus disesuaikan dengan kompleksitas perusahaan dengan tetap memperhatikan efektifitas dalam pengambilan keputusan.

\section{Komite yang dibentuk Komisaris}

Dalam melaksanakan tugas pengawasannya, dewan komisaris dapat membentuk komite yang akan membantu tugas-tugas dewan komisaris. Bagi perusahaan yang sahamnya tercatat di bursa efek, perusahaan negara, perusahaan daerah, perusahaan yang menghimpun dan mengelola dana masyarakat, perusahaan yang produk atau jasanya digunakan oleh masyarakat luas, serta perusahaan yang mempunyai dampak luas terhadap kelestarian lingkungan, sekurangkurangnya harus membentuk Komite Audit, sedangkan komite lain dibentuk sesuai dengan kebutuhan.

Berikut ini dijelaskan secara rinci mengenai tugas dari komite-komite penunjang Komisaris. 
1) Komite Audit

Komite Audit bertugas membantu dewan komisaris untuk memastikan bahwa: (i) laporan keuangan disajikan secara wajar sesuai dengan prinsip akuntansi yang berlaku umum, (ii) struktur pengendalian internal perusahaan dilaksanakan dengan baik, (iii) pelaksanaan audit internal maupun eksternal dilaksanakan sesuai dengan standar audit yang berlaku, dan (iv) tindak lanjut temuan hasil audit dilaksanakan oleh manajemen. Disamping itu, Komite Audit juga bertugas memproses calon auditor eksternal termasuk imbalan jasanya untuk disampaikan kepada Dewan Komisaris.

Pedoman Good Corporate Governance tidak mengatur banyaknya anggota Komite Audit dalam suatu perusahaan namun harus disesuaikan dengan kompleksitas Perusahaan dengan tetap memperhatikan efektifitas dalam pengambilan keputusan. Bagi perusahaan yang sahamnya tercatat di bursa efek, perusahaan negara, perusahaan daerah, perusahaan yang menghimpun dan mengelola dana masyarakat, perusahaan yang produk atau jasanya digunakan oleh 
masyarakat luas, serta perusahaan yang mempunyai dampak luas terhadap kelestarian lingkungan, Komite Audit diketuai oleh Komisaris Independen dan anggotanya dapat terdiri dari Komisaris dan atau pelaku profesi dari luar perusahaan. Salah seorang anggota memiliki latar belakang dan kemampuan akuntasi dan atau keuangan.

Pengaturan mengenai jumlah Komite Audit bagi Emiten dan Perusahaan Publik diatur dalam peraturan Bapepam-LK No.IX.I.5 tentang Pembentukan dan Pedoman Pelaksanaan Kerja Komite Audit. Dalam peraturan tersebut Emiten dan Perusahaan Publik diwajibkan membentuk Komite Audit yang berjumlah sekurang-kurangnya tiga orang dimana salah satunya merupakan Komisaris Independen Perusahaan dan bertindak sebagai ketua Komite Audit.

Adapun persyaratan anggota Komite Audit sebagai berikut :

1) Memiliki integritas yang tinggi, kemampuan, pengetahuan dan pengalaman yang memadai sesuai latar belakang pendidikannya 
2) Mempunyai kemampuan komunikasi yang baik

3) Memiliki kemampuan yang cukup untuk membaca dan memahami laporan keuangan

4) Memiliki pengetahuan yang memadai mengenai peraturan perundang-undangan dibidang pasar modal

5) Salah satu anggota memiliki latar belakang pendidikan akuntansi atau keuangan

6) Bukan merupakan orang dalam Kantor Akuntan Publik, Konsultan Hukum mapupun Pihak lain yang memberikan jasa audit, non audit maupun jasa

7) Tidak mempunyai hubungan keluarga karena perkawinan dan keturunan sampai derajat kedua dengan Direksi, Komisaris dan Penegang saham Utama Emiten maupun Perusahaan Publik

8) Tidak mempunyai hubungan usaha baik langsung mapun tidak langsung dengan kegiatan usaha Emiten maupun Perusahaan Publik

9) Tidak memiliki saham Emiten atau Perusahaan Publik baik langsung maupun tidak langsung 
10) Bukan merupakan orang yang berwenang dan bertanggungjawab merencanakan, memimpin dan mengendalikan kegiatan Emiten maupun Perusahaan Publik dalam waktu enam bulan terakhir sebelum diangkat

b. Komite Nominasi dan Remunerasi

Komite Nominasi dan Remunerasi bertugas membantu Dewan Komisaris dalam menetapkan kriteria pemilihan calon anggota Dewan Komisaris dan Direksi serta sistem remunerasinya; membantu Dewan Komisaris mempersiapkan calon anggota Dewan Komisaris dan Direksi dan mengusulkan besaran remunerasinya. Dewan Komisaris dapat mengajukan calon tersebut dan remunerasinya untuk memperoleh keputusan RUPS dengan cara yang sesuai ketentuan Anggaran Dasar. Bagi perusahaan yang sahamnya tercatat di bursa efek, perusahaan negara, perusahaan daerah, perusahaan yang menghimpun dan mengelola dana masyarakat, perusahaan yang produk atau jasanya digunakan oleh masyarakat luas, serta perusahaan yang mempunyai dampak luas terhadap kelestarian 
lingkungan, Komite Nominasi dan Remunerasi diketuai oleh Komisaris Independen dan anggotanya dapat terdiri dari Komisaris dan atau pelaku profesi dari luar perusahaan. Selanjutnya, keberadaan Komite Nominasi dan Remunerasi serta tata kerjanya dilaporkan dalam RUPS.

c. Komite Kebijakan Risiko

Komite Kebijakan Risiko bertugas membantu Dewan Komisaris dalam mengkaji sistem manajemen risiko yang disusun oleh Direksi serta menilai toleransi risiko yang dapat diambil oleh perusahaan. Anggota Komite Kebijakan Risiko terdiri dari anggota Dewan Komisaris, namun bilamana perlu dapat juga menunjuk pelaku profesi dari luar perusahaan.

d. Komite Kebijakan Corporate Governance

Komite Kebijakan Corporate Governance bertugas membantu Dewan Komisaris dalam mengkaji kebijakan GCG secara menyeluruh yang disusun oleh Direksi serta menilai konsistensi penerapannya, termasuk yang bertalian dengan etika bisnis dan tanggung jawab sosial perusahaan (corporate social responsibility). Anggota Komite Kebijakan Corporate 
Governance terdiri dari anggota Dewan Komisaris, namun bilamana perlu dapat juga menunjuk pelaku profesi dari luar perusahaan. Bila dipandang perlu, Komite Kebijakan Corporate Governance dapat digabung dengan Komite Nominasi dan Remunerasi.

\section{Fungsi Internal Audit}

Sebagaimana dijelaskan di atas, Pedoman Good Corporate Governance mensyaratkan perlunya pengendalian internal dalam rangka menjaga kekayaan dan kinerja perusahaan serta memenuhi peraturan perundang-undangan. Bagi perusahaan yang sahamnya tercatat di bursa efek, perusahaan negara, perusahaan daerah, perusahaan yang menghimpun dan mengelola dana masyarakat, perusahaan yang produk atau jasanya digunakan oleh masyarakat luas, serta perusahaan yang mempunyai dampak luas terhadap kelestarian lingkungan, harus memiliki satuan kerja pengawasan internal. Satuan kerja atau fungsi pengawasan internal bertugas membantu Direksi dalam memastikan pencapaian tujuan dan kelangsungan usaha dengan: 
a. melakukan evaluasi terhadap pelaksanaan program perusahaan

b. memberikan saran dalam upaya memperbaiki efektifitas proses pengendalian risiko

c. melakukan evaluasi kepatuhan perusahaan terhadap peraturan perusahaan, pelaksanaan GCG dan perundangundangan

d. memfasilitasi kelancaran pelaksanaan audit oleh auditor eksternal

Satuan kerja atau pemegang fungsi pengawasan internal bertanggung jawab kepada Direktur Utama atau Direktur yang membawahi tugas pengawasan internal. Satuan kerja pengawasan internal mempunyai hubungan fungsional dengan Dewan Komisaris melalui Komite Audit.

Sejalan dengan Pedoman tersebut, Bapepam-LK mengatur secara khusus mengenai keberadaan unit internal audit bagi Emiten dan Perusahaan Publik. Dalam peraturan No.IX.I.7 tentang Pembentukan dan Pedoman Penyusunan Piagam Unit Audit Internal dinyatakan bahwa Emiten dan Perusahaan Publik wajib membentuk 
Unit Audit Internal yang menjalankan fungsi Audit Internal, yaitu memberikan keyakinan (assurance) dan konsultasi yang bersifat independen dan obyektif, dengan tujuan untuk meningkatkan nilai dan memperbaiki operasional perusahaan, melalui pendekatan yang sistematis, dengan cara mengevaluasi dan meningkatkan efektivitas manajemen risiko, pengendalian, dan proses tata kelola perusahaan.

Jumlah auditor dalam unit tersebut disesuaikan dengan besaran dan kompleksitas kegitan usaha perusahaan dimana sekurang-kurangnya berjumlah satu orang. Adapun persyaratan bagi auditor internal yang duduk dalam Unit Audit Internal sekurang-kurangnya adalah :

a. memiliki integritas dan perilaku yang profesional, independen, jujur, dan obyektif dalam pelaksanaan tugasnya;

b. memiliki pengetahuan dan pengalaman mengenai teknis audit dan disiplin ilmu lain yang relevan dengan bidang tugasnya; 
c. memiliki pengetahuan tentang peraturan perundang-undangan di bidang pasar modal dan peraturan perundang-undangan terkait lainnya;

d. memiliki kecakapan untuk berinteraksi dan berkomunikasi baik lisan maupun tertulis secara efektif;

e. wajib mematuhi standar profesi yang dikeluarkan oleh asosiasi Audit Internal;

f. wajib mematuhi kode etik Audit Internal;

g. wajib menjaga kerahasiaan informasi dan/atau data perusahaan terkait dengan pelaksanaan tugas dan tanggung jawab Audit Internal kecuali diwajibkan berdasarkan peraturan perundangundangan atau penetapan/putusan pengadilan;

h. memahami prinsip-prinsip tata kelola perusahaan yang baik dan manajemen risiko; dan

i. bersedia meningkatkan pengetahuan, keahlian dan kemampuan profesionalismenya secara terusmenerus.

Kedudukan Unit Internal Audit ini cukup kuat mengingat pengangkatan dan pemberhentian Kepala Unit Audit Internal dilakukan oleh direktur utama 
dengan persetujuan dewan komisaris. Disamping itu, meskipun Kepala Unit Audit Internal bertanggung jawab kepada direktur utama namun laporan hasil audit wajib disampaikan juga kepada dewan komisaris.

\section{Etika Bisnis dan Pedoman Perilaku}

Untuk mencapai keberhasilan dalam jangka panjang, pelaksanaan prinsip-prinsip Good Corporate Governance perlu dilandasi oleh integritas yang tinggi. Oleh karena itu, diperlukan pedoman perilaku yang dapat menjadi acuan bagi organ perusahaan dan semua karyawan dalam menerapkan nilai-nilai (values) dan etika bisnis sehingga menjadi bagian dari budaya perusahaan. Prinsip-prinsip dasar yang harus dimiliki oleh perusahaan adalah:

a. memiliki nilai-nilai perusahaan yang menggambarkan sikap moral perusahaan dalam pelaksanaan usahanya.

b. Untuk dapat merealisasikan sikap moral dalam pelaksanaan usahanya, perusahaan harus memiliki rumusan etika bisnis yang disepakati oleh organ perusahaan dan semua karyawan. 
Pelaksanaan etika bisnis yang berkesinambungan akan membentuk budaya perusahaan yang merupakan manifestasi dari nilai-nilai perusahaan.

c. Nilai-nilai dan rumusan etika bisnis perusahaan perlu dituangkan dan dijabarkan lebih lanjut dalam pedoman perilaku agar dapat dipahami dan diterapkan.

\section{Remunerasi Dewan Komisaris dan Direksi}

Pedoman Umum Good Corporate Governance tidak mengatur keterbukaan informasi mengenai remunerasi bagi dewan komisaris dan direksi. Namun bagi Emiten dan Perusahaan Publik, Bapepam-LK mewajibkan pengungkapan dalam laporan tahunan mengenai prosedur penetapan dan besarnya remunerasi anggota dewan komisaris dan direksi. Kewajiban ini diatur dalam peraturan Bapepam-LK No.X.K.6 tahun 2006 tentang Kewajiban Penyampaian laporan tahunan bagi Emiten dan Perusahaan Publik. 


\section{B. Pedoman Corporate Governance di Singapura}

\section{Metode Penerapan Pedoman Good Corporate} Governance

Metode penerapan Pedoman Good Corporate Governance bersifat comply and explain. Selanjutnya berdasarkan ketentuan pencatatan efek di Bursa efek Singapore mengharuskan perusahaan tercatat untuk mengungkapkan praktik tata kelola mereka dalam laporan tahunan dengan referensi khusus kepada prinsip-prinsip yang terdapat dalam Pedoman. Perusahaan juga wajib mengungkapkan dan menjelaskan setiap perbedaan pelaksanaannya dari Pedoman tersebut. Perusahaan juga didorong untuk melakukan konfirmasi positif tentang pemenuhan prinsip-prinsip tata kelola dan mengungkapkan setiap ketidak patuhan terhadap prinsip-prinsip tersebut dalam laporan tahunan perusahaan.

\section{Sanksi atas ketidakpatuhan}


Penerapan Pedoman Good Corporate Governance oleh perusahaan hanya bersifat voluntary. Oleh karena itu, tidak ada sanksi bagi perusahaan yang tidak menerapkannya. Akan tetapi, perusahaan harus menjelaskan dengan rinci alasan untuk tidak menerapkannya.

\section{Ruang lingkup Pedoman Good Corporate} Governance

Ruang lingkung Tata Kelola perusahaan
a. Board Matters
b. Remuneration Matters
c. Accountability and Audit
d. Communication with Shareholders
e. Disclosure of Corporate Governance Arrangements

\section{Komposisi dan persyaratan Komisaris \\ Independen}

Untuk membentuk elemen yang kuat dan independen dari dewan, perlu adanya komisaris independen yang sekurang-kurangnya berjumlah 
sepertiga dari jumlah anggota dewan. Adapun yang dimaksud dengan komisaris independen adalah orang yang tidak memiliki hubungan dengan perusahaan maupun afiliasinya seperti anak perusahaan atau induk perusahaan. Hubungan afiliasi ini dapat mempengaruhi independensi dari penilaian atas keputusan yang diambil. Contoh hubungan yang dianggap dapat menjadikan seorang komisaris tidak independen, meliputi:

a. Komisaris yang saat ini masih dipekerjakan oleh perusahaan atau afiliasinya untuk saat tiga tahun terakhir;

b. seorang komisaris yang memiliki keluarga dekat dengan anggota komisaris atau salah satu komisaris yang sudah bekerja selama tiga tahun terakhir atau mempunyai hubungan dengan anggota direksi yang remunerasinya ditentukan oleh komite remunirasi. 
c. seorang komisaris, atau seorang anggota keluarga dekat yang menerima kompensasi dari perusahaan atau salah satu anak perusahaan selain kompensasi yang diberikan kepada anggota dewan dalam tahun berjalan atau tahun sebelumnya

d. seorang komisaris, atau seorang anggota keluarga dekat, menjadi pemegang saham substansial atau seorang partner (mempunyai 5\% atau lebih saham), karyawan eksekutif, atau seorang komisaris dari sebuah perusahaan yang memberikan atau menerima pembayaran secara signifikan dari perusahaan atau salah satu anak perusahaan selama tahun berjalan dan tahun sebelumnya (S\$200.000 dianggap sebagai pembayaran yang signifikan)

Jika perusahaan mengangkat seorang komisaris independen yang memiliki salah satu hubungan diatas maka perusahaan harus mengungkapkan 
dan menjelaskan mengapa komisaris tersebut tetap dianggap independen.

\section{Komposisi/Jumlah Direksi}

Setiap perusahaan harus dipimpin oleh Dewan yang efektif untuk memimpin dan mengendalikan perusahaan. Dewan ini secara kolektif bertanggung jawab atas keberhasilan perusahaan. Dewan bekerja dengan manajemen untuk mencapai tujuan perusahaan dan manajemen bertanggung jawab kepada Dewan.

Setiap anggota direksi harus menerima pelatihan yang tepat mengenai tugas dan tanggungjawabnya dan bagaimana melaksanakan tugas-tugas tersebut ketika ia pertama ditunjuk sebagai anggota dewan. Pelatihan ini dilakukan untuk memastikan bahwa anggota direksi yang baru diangkat memahami bisnis perusahaan. Anggota direksi juga harus mengikuti pendidikan atau pelatihan lebih lanjut terutama tentang ketentuan atau peraturan-peraturan yang berlaku termasuk perubahannya. 
Untuk memastikan keseimbangan kekuasaan dan wewenang dan menghindari kekuasaan absolut atas perusahaan yang dimiliki salah satu pihak, harus ada pembagian tanggung jawab yang jelas antara dewan komisaris dan anggota direksi perusahaan.

Ketua dewan dan Chief Executive Officer pada prinsipnya harus terpisah, untuk menjamin perimbangan kekuasaan, meningkatkan akuntabilitas dan kapasitas Dewan dalam pengambilan keputusan yang independen. Pembagian tanggung jawab antara Ketua dewan dan Chief Executive Officer harus secara jelas ditetapkan secara tertulis dan disetujui oleh Dewan. Selain itu, perusahaan harus mengungkapkan apabila Ketua dewan dan Chief Executive Officer mempunyai hubungan afiliasi. 


\section{Komite yang dibentuk Komisaris}

Dalam menjalankan tugasnya, Komisaris dapat membentuk Komite. Ada beberapa prinsip yang direkomendasikan terkait komite yang dibentuk komisaris yaitu :

\section{a. Komite Audit}

Dewan harus membentuk Komite Audit dan menyusun kerangka acuan tertulis yang menjelaskan wewenang dan tugas komite. Komite audit sekurang-kurangnya beranggotakan tiga komisaris dimana mayoritas merupakan komisaris independen. Komite audit diketuai oleh komisaris independen. Dewan harus memastikan bahwa anggota komite audit telah memenuhi persyaratan yang diperlukan untuk melaksanakan tanggung jawab mereka. Persyaratan tersebut antara lain sekurang-kurangnya dua anggota komite audit harus memiliki keahlian dibidang akuntansi atau keuangan atau pengalaman yang terkait. Adapun wewenang komite audit antara lain harus memiliki otoritas yang dinyatakan secara eksplisit untuk 
menyelidiki setiap permasalahan perusahaan, mempunyai akses penuh dan bekerjasama dengan manajemen serta mempunyai wewenang penuh untuk mengundang setiap anggota dewan komisaris atau direksi untuk menghadiri rapat. Komite audit juga harus mempunyai sumber daya yang memadai untuk melaksanakan tugastugasnya dengan baik. Adapun tugas dan tanggungjawab komite audit mencakup:

1) menelaah ruang lingkup, hasil audit, efektivitas biaya, independensi dan obyektivitas auditor eksternal. Apabila auditor eksternal juga memberikan kontribusi yang besar dalam jasa non-audit kepada perusahaan, komite audit harus menjaga objektivitas dan menyeimbangkan jasa yang diberikan tersebut;

2) menelaah masalah-masalah signifikat terkait dengan laporan keuangan dan penilaian yang dilakukan dewan sehingga dapat menjamin integritas laporan keuangan 
perusahaan dan setiap informasi yang diungkapkan perusahaan terkait dengan kinerja keuangan perusahaan;

3) menelaah kecukupan pengendalian internal perusahaan

4) mengkaji efektivitas fungsi audit internal perusahaan, dan

5) membuat rekomendasi kepada Dewan tentang pengangkatan, pengangkatan kembali dan pemecatan auditor eksternal, dan menyetujui remunerasi dan persyaratan keterlibatan auditor eksternal.

6) bertemu dengan auditor eksternal, dan dengan internal auditor, tanpa kehadiran Manajemen perusahaan, setidaknya setiap tahun.

7) mengkaji independensi auditor eksternal setiap tahun.

8) Menelaah perjanjian-perjanjian yang memungkinkan munculnya permasalahan- 
permasalahan terkait dengan laporan keuangan atau lainnya dan memastikan dpat dilakukan pemeriksaan secara independen atas hal tersebut.

Dewan harus mengungkapkan nama-nama anggota komite audit dan rincian kegiatan Komite dalam laporan tahunan perusahaan.

\section{b. Komite Nominasi}

Perusahaan harus membentuk Komite Nominasi untuk membuat rekomendasi kepada Dewan terhadap semua penunjukkan anggota dewan. Komite Nominasi harus terdiri dari setidaknya tiga direktur non-eksekutif dimana mayoritas dari anggota komite nominasi termasuk Ketua komite harus independen. Selain itu, Ketua komite nominasi bukan merupakan atau tidak terkait langsung dengan pemegang saham substansial (5\% atau lebih dalam kepemilikan hak suara perusahaan). Keberadaan komite nominasi ini harus diungkapkan dalam laporan tahunan. 
Komite Nominasi harus memiliki pedoman secara tertulis yang memuat tanggung jawab anggotanya.

Komite Nominasi harus mempunyai tanggung jawab untuk re-nominasi dengan memperhatikan kontribusi anggota dewan dan kinerja (misalnya kehadiran, kesiapan dan partisipasi) termasuk, jika ada, sebagai komisaris independen. Semua anggota dewan diminta mendaftarkan kembali pencalonan dan pemilihan sebagai anggota dewan secara berkala, setidaknya setiap tiga tahun.

Komite Nominasi harus mempunyai tanggung jawab untuk memastikan pemenuhan kriteria komisaris independen setiap tahunnya. Apabila Komite Nominasi menemukan bahwa seorang komisaris independen memenuhi satu atau beberapa kriteria tidak independen sebagaimana telah ditetapkan namun tetap dianggap independen, perusahaan harus melakukan pengungkapan yang cukup mengenai hal tersebut. Namun demikian, Komite Nominasi harus memiliki 
kewenangan untuk menentukan bahwa seorang komisaris tidak independen.

Apabila seorang komisaris memiliki rangkapan jabatan sebagai komisaris di beberapa tempat, harus dipastikan bahwa yang bersangkutan memberikan waktu dan perhatian yang cukup terhadap masing-masing perusahaan. Komite nominasi harus memutuskan apakan direktur tersebut mampu dan telah memadai dalam melakukan tugas dan tanggung jawabnya sebagai direktur perusahaan. Pedoman internal harus mengadopsi komitmen tentang direksi yang memiliki beberapa peran sebagai direktur dibeberapa dewan perusahaan lainnya. Proses pemilihan dan pengangkatan komisaris baru oleh dewan harus diungkapkan secara jelas, termasuk pengungkapan tentang proses pencarian dan nominasinya.

Informasi penting mengenai anggota dewan komisaris dan direksi, seperti kualifikasi pendidikan, pengalaman, kepemilikan saham di perusahaan 
dan anak perusahaan, keterlibatan dalam komite (baik sebagai anggota atau Ketua), tanggal pengangkatan pertama sebagai komisaris atau direktur, tanggal terakhir terpilinnya kembali sebagai komisaris atau direktur, jabatan komisaris atau direktur baik sekarang maupun tiga tahun sebelumnya di perusahaan lain, harus diungkapkan dalam laporan tahunan. Nama-nama anggota dewan komisaris dan direksi yang calonkan dalam pengangkatan atau pemilihan kembali harus disertai dengan informasi tersebut di atas. Hal ini untuk memberikan informasi yang cukup bagi pemegang saham dalam membuat keputusan.

\section{c. Komite Remunerasi}

Dewan harus membentuk Komite Remunerasi yang sepenuhnya terdiri dari direktur non-eksekutif (komisaris) yang mayoritas anggotanya termasuk Ketuanya harus independen. Hal ini untuk meminimalkan potensi terjadinya benturan kepentingan. Adapun tugas dan tanggung jawab komite remunerasi adalah : 
1) Komite

Remunerasi

akan

merekomendasikan

kepada

Dewan

kebijakan remunerasi dan paket remunerasi untuk setiap anggota dewan komisaris dan CEO (atau tingkat eksekutif setara) jika CEO bukan anggota dewan. Komite remunerasi menyerahkan rekomendasi remunerasi kepada dewan untuk disahkan. Rekomendasi yang disampaikan komite mencakup semua aspek remunerasi, namun tidak terbatas pada fee anggota dewan komisaris, gaji, tunjangan, bonus, opsi, dan manfaat dalam bentuk. Komite remunerasi juga meninjau remunerasi manajemen senior.

2) Jika diperlukan, komite remunerasi dapat meminta pendapat pihak ahli baik dari dalam maupun dari luar perusahaan terkait penentuan remunerasi semua anggota dewan komisaris dan direksi. 
3) Komite remunerasi harus menelaah apakah anggota dewan memenuhi syarat untuk imbalan menerima manfaat berdasarkan skema insentif yang bersifat jangka panjang. Biaya dan manfaat dari skema insentif jangka panjang harus dievaluasi secara cermat.

\section{d. Fungsi Internal Audit}

Perusahaan harus membentuk suatu fungsi audit internal yang independen dari kegiatan yang mereka audit. Secara garis besar Auditor Internal harus memberikan pelaporan kepada ketua komite audit meskipun secara administratif auditor internal juga akan melapor kepada Chief Executive Officer. Auditor Internal harus memenuhi atau melebihi standar yang ditetapkan oleh organisasi profesi yang diakui secara nasional atau tingkat internasional, termasuk standar untuk Praktik Profesional Internal Audit yang ditetapkan Ikatan Auditor Internal. Komite Audit harus memastikan bahwa fungsi audit internal memiliki sumber daya 
cukup dan memiliki kontrol yang tepat dalam perusahaan. Untuk menghindari keraguan, fungsi audit internal dapat ditugaskan kepada kantor akuntan dan auditor yang dapat dipercaya. Komite Audit harus, setidaknya sekali dalam setahun, memastikan kecukupan fungsi audit internal.

\section{e. Etika Bisnis dan Pedoman Perilaku}

\section{Dalam Pedoman Good Corporate} Governance tersebut tidak terdapat ketentuan yang mengatur mengenai keberadaan etika bisnis dan pedoman perilaku (code of conduct) yang harus dimiliki dan dilaksanakan oleh perusahaan.

\section{f. Remunerasi Direksi dan Dewan Komisaris}

Remunerasi Dewan harus sebanding dengan tingkat industri di mana perusahaan berada. Tingkat remunerasi harus memadai untuk menarik, mempertahankan dan memotivasi anggota dewan untuk menjalankan perusahaan dengan baik tetapi perusahaan harus menghindari untuk membayar secara berlebihan dalam 
mencapai tujuan ini. Satu hal terpenting dalam penyusunan remunerasi direksi adalah remunerasi harus dibuat secara terstruktur sehingga ada kesesuaian antara penghargaan yang diberikan dengan kinerja perusahaan dan individu. Hal-hal yang harus diperhatikan dalam menetapkan remunerasi yaitu :

a. Unsur-unsur kinerja yang berhubungan dengan remunerasi harus dirancang untuk menyelaraskan kepentingan direksi dengan pemegang saham dan terdapat hubungan antara penghargaan dengan kinerja perusahaan dan individu.

b. Remunerasi komisaris harus sesuai dengan besarnya kontribusi yang diberikan, dengan mempertimbangkan faktor-faktor seperti usaha dan waktu yang dihabiskan, dan tanggung jawab komisaris. Komisaris seharusnya tidak akan mendapatkan kompensasi apabila mereka tidak independen. 
c. Dalam hal jasa yang diberikan anggota dewan didasarkan kontrak, harus ada periode pengangkatan yang tertentu untuk anggota direksi. Perlu dihindari kontrak yang terlalu lama atau adanya klausul penggantian direksi yang sangat sulit.Komite remunerasi juga harus menelaah kesepakatan kompensasi yang harus diberikan kepada direksi dalam hal terjadi penghentian direksi sebelum selesainya kontrak tersebut. Komite remunerasi harus dapat bersikap adil dan menghindari pemberian kompensasi untuk kinerja yang buruk.

Pengungkapan remunerasi diatur sebagai berikut :

a. Setiap perusahaan harus menyediakan pengungkapan yang jelas tentang kebijakan remunerasinya, tingkat dan komponen remunerasi, dan prosedur untuk pengaturan remunerasi dalam laporan tahunan perusahaan. Pengungkapan remunirasi 
dalam laporan tahunan agar investor dapat memahami link antara remunerasi yang dibayarkan kepada direksi dan eksekutif kunci, dengan kinerja perusahaan.

b. Perusahaan harus melaporkan kepada pemegang saham setiap tahun tentang remunerasi anggota dewan dan setidaknya 5 top eksekutif perusahaan (yang bukan merupakan anggota dewan) perusahaan. Laporan remunerasi tahunan ini merupakan bagian dari, atau dilampirkan pada laporan tahunan perusahaan. Hal ini menjadi sarana utama bagi perusahaan untuk melaporkan kepada pemegang saham mengenai remunerasi. Para anggota komite remunirasi harus tercantum dalam laporan tahunan perusahaan.

c. Laporan harus menetapkan nama direksi dan setidaknya 5 top eksekutif (yang bukan merupakan anggota dewan) yang mempunyai remunerasi produktif sebesar $\mathrm{S}$ 
\$ 250.000. Harus diungkapkan pula remunerasi masing-masing anggota dewan yang meliputi gaji pokok/ gaji tetap atau variabel pendapatan berbasis kinerja/bonus, tunjangan dan opsi saham yang diberikan dan insentif lainnya jangka panjang.

d. Untuk transparansi, laporan harus mengungkapkan rincian yang sama baik untuk remunerasi karyawan yang mempunyai hubungan keluarga langsung dengan anggota direktur atau CEO, dan remunerasinya lebih dari S\$ 150.000 pada tahun yang bersangkutan. Hal ini dapat dilakukan tanpa mencantumkan nama- (noname basis) namun dipisahkan dan disebutkan secara jelas antara anggota dewan komisaris dan direksi.

e. Laporan ini juga harus memuat rincian skema saham karyawan yang memungkinkan pemegang saham dapat menilai manfaat dan biaya potensial yang 
diperlukan perusahaan. Yang terpenting dalam hal skema saham adalah termasuk jumlah opsi saham yang diberikan, metodologi penilaian opsi saham, harga pelaksanaan opsi yang diberikan, apakah harga pelaksanaan disesuaikan dengan harga pasar atau telah ditentukan sesuai pada tanggal pemberian, harga pasar pada saat pelaksanaan, jadwal vesting, dan pernyataan untuk istilah yang diadopsi, harus diungkapkan.

\section{Pedoman Corporate Governance di Malaysia}

Pedoman Good Corporate Governance (The Malaysian Code on Corporate Governance) ini diterbitkan oleh Bursa Efek Malaysia dan kewajiban untuk melaksanakan Pedoman ini diatur dalam peraturan tentang pencatatan efek di bursa efek tersebut. Pedoman ini diterbitkan pada tahun 2007 dan merupakan revisi atas pedoman yang diterbitkan sebelumnya. 


\section{Metode penerapan Pedoman Good Corporate}

\section{Governance}

Penerapan Pedoman Good Corporate Governance bagi perusahaan bersifat comply and explain. Denagan demikian tidak ada sanksi apabila perusahaan tidak menerapkan seluruh aspek dalam Pedoman tersebut. Bagi perusahaan yang tercatat di bursa efek Malaysia, prinsip-prinsip Good Corporate Governance dan praktik-praktik terbaik yang telah diterapkan perusahaan wajib diungkapkan dalam laporan tahunan. Perusahaan juga wajib mengidentifikasi prinsip dan praktik terbaik yang tidak dilaksanakan disertai alasan atas ketidakpatuhan tersebut. Apabila perusahaan mengadopsi praktek tata kelola negara lain, hal ini juga harus diungkapkan.

\section{Sanksi atas ketidakpatuhan terhadap Pedoman Good Corporate Governance} Penerapan Pedoman Good Corporate Governance bersifat comply and explain sehingga tidak terdapat sanksi dalam hal perusahaan tidak 
menerapkan seluruh aspek dalam Pedoman Good Corporate Governance. Namun terdapat kewajiban untuk mengungkapkan pelaksanaan dari Pedoman tersebut dalam laporan tahunan. Dengan demikian bagi perusahaan yang tercatat atau akan mencatatkan sahamnya di bursa tidak mengungkapkan dalam laporan tahunannya terkait dengan penerapan tata kelola, Bursa Malaysia dapat mengambil tindakan terhadap perusahaan atau direksi sebagaimana tercantum dalam Persyaratan Listing di Bursa Malaysia.

\section{Ruang lingkup Pedoman Good Corporate} Governance

Pedoman Good Corporate Governanc terdiri dari tiga bagian yaitu :

a. Bagian 1 :

Memuat prinsip-prinsip Good Corporate Governance yang luas yang berlaku di Malaysia. Tujuan dari prinsip-prinsip ini adalah untuk memungkinkan fleksibilitas perusahaan dalam 
menerapkan prinsip-prinsip sesuai dengan keadaan masing-masing perusahaan.

b. Bagian 2 :

Menetapkan praktik-praktik terbaik dalam tata kelola perusahaan. mengidentifikasi seperangkat pedoman atau praktek yang dimaksudkan untuk membantu perusahaan dalam merancang pendekatan mereka terhadap tata kelola perusahaan yang baik bagi perusahaannya.

c. Bagian 3 :

Dorongan atau himbauan bagi pihak-pihak selain tersebut di atas yang bersifat sukarela. Hal ini tidak ditujukan kepada perusahaan yang terdaftar tetapi untuk investor dan auditor untuk meningkatkan peran mereka dalam tata kelola perusahaan.

Adapun ruang lingkup dari Pedomana Good Corporate Governance tersebut adalah :

a. The Board Structure, Duties and Effectiveness

b. The Audit Committee and its Challenges

c. Assessing the Risk and Control Environment 
d. Effective Oversight of Financial Reporting

e. Internal and External Audit: "Eyes And Ears" of Audit Committee

f. Conflict of Interest and Related Party Transactions

g. Nominating Committee

h. Remuneration Committee

i. Shareholder Relations

\section{Jumlah dan persyaratan Komisaris Independen}

Direktur non-eksekutif atau komisaris dalam two tier system harus orang yang mempunyai reputasi baik, kredibilitas dan memiliki keterampilan yang diperlukan dan pengalaman untuk memberikan penilaian secara independen terhadap isu-isu strategi, kinerja dan sumber daya perusahaan, termasuk kontrak perjanjian dan standar perilaku. Agar efektif, jumlah direktur non- 
eksekutif yang independen setidaknya satu per tiga (1/3) dari anggota dewan.

Dalam keadaan dimana sebuah perusahaan memiliki pemegang saham yang signifikan, di samping persyaratan bahwa sepertiga dewan harus terdiri dari direksi non-eksekutif independen, dewan harus terdiri dari sejumlah direksi non-eksekutif yang merefleksikan pemegang saham perusahaan selain pemegang saham yang signifikan. Untuk tujuan ini, "pemegang saham yang signifikan" didefinisikan sebagai pemegang saham yang memiliki suara mayoitas dalam pemilihan direksi non-eksekutif. Dalam keadaan dimana tidak terdapat pemegang saham mayoritas tetapi terdapat pemegang saham yang memiliki porsi saham terbesar, dewan harus melakukan penilaian dalam menentukan jumlah direksi non-eksekutif yang akan mencerminkan kepentingan dari sisa pemegang saham lainnya. 


\section{Komposisi DireksI}

Malaysia menganut one board sistem dimana kedudukan dewan komisaris dan direksi terletak dalam satu dewan dengan demikian pengaturan mengenai direksi menjadi satu kesatuan dengan dewan komisaris. Dalam Pedoman Good Corporate Governance disyaratkan setiap perusahaan terdaftar harus dipimpin oleh suatu dewan yang efektif yang harus memimpin dan mengendalikan perusahaan. Dewan harus mencakup keseimbangan antara direktur eksekutif dan direktur non-eksekutif (termasuk non-eksekutif independen) sedemikian rupa sehingga tidak ada individu atau kelompok tertentu yang dapat mendominasi pengambilan keputusan dewan.

Harus ada pembagian tanggung jawab yang jelas antara (Chairman and Chief executive Officer). Ketua Dewan akan memastikan keseimbangan kekuasaan dan wewenang, sehingga tidak ada individu yang tidak terikat dengan keputusan perusahaan. Ketika terjadi penggabungan peran antara ketua dan CEO harus 
ada elemen independen di dalam board. Keputusan untuk menggabungkan peran ketua dan CEO harus secara terbuka dijelaskan dalam laporan tahunan.Setiap dewan harus memastikan jumlah yang tepat, dengan maksud untuk menentukan dampak jumlah anggota dewan terhadap efektivitas pelaksanaan tugas dan fungsinya.

\section{Komite yang dibentuk Komisaris}

\section{a. Komite audit}

Dewan harus membentuk Komite Audit terdiri dari setidaknya tiga anggota, yang mayoritas dari mereka adalah independen. Semua anggota komite audit harus direksi non-eksekutif. Dewan harus menyediakan pedoman komite audit secara tertulis sebagai kerangka acuan yang jelas terkai dengan kewenangan dan tugasnya. Semua anggota komite audit harus mengerti tentang finansial dan setidaknya salah satu anggota komite audit harus menjadi anggota asosiasi akuntansi atau sejenisnya. Adapun tugas komite audit harus mencakup : 
1) mempertimbangkan penunjukan auditor eksternal, biaya audit dan pertanyaan pengunduran diri atau pemecatannya

2) mendiskusikan dengan auditor eksternal sebelum audit dimulai mengenai sifat dan lingkup audit, dan memastikan adanya koordinasi apabila audit yang dilakukan melibatkan lebih dari satu auditor;

3) melakukan penelaahan laporan keuangan triwulanan dan akhir tahun dengan fokus terutama pada :

a. setiap perubahan kebijakan dan praktik akuntansi

b. penyesuaian yang signifikan yang timbul dari audit

c. asumsi-asumsi kelangsungan usaha perusahaan

d. kesesuaian dengan standar akuntansi dan persyaratan hukum lainnya 
4) mendiskusikan masalah-masalah yang timbul dalam audit interim dan audit tahunan dan masalah-masalah lain yang ingin dibahas oleh auditor (bila diperlukan, tanpa adanya pihak manajemen)

5) menelaah external auditor's management letter dan tanggapan manajemen;

6) melakukan hal-hal terkait dengan fungsi audit internal:

a) penelaahan kecukupan ruang lingkup fungsi dan sumber daya audit internal, dan bahwa audit internal memiliki otoritas yang diperlukan untuk melaksanakan tugasnya

b) review atas program audit internal dan hasil dari proses audit internal dan, jika perlu, memastikan bahwa ada tindakan yang tepat yang diambil pada rekomendasi dan fungsi audit internal; 
c) mereview setiap penilaian atau kinerja fungsi audit internal;

d) menyetujui setiap penunjukan atau pemberhentian anggota staf senior fungsi audit internal, dan

e) tahu tentang pengunduran diri anggota staf audit internal dan menyediakan kesempatan bagi anggota staf yang mengundurkan diri untuk mengajukan alasan pengundurkan diri

7) Untuk setiap transaksi yang terkait dalam mempertimbangkan pihak yang mungkin masuk dalam perusahaan atau kelompok

8) Untuk mempertimbangkan temuan utama dari penyelidikan internal dan respon manajemen

9) Untuk mempertimbangkan topik lain seperti yang didefinisikan oleh pengurus. 


\section{b. Komite Nominasi}

Dewan perusahaan harus menunjuk sebuah komite nominasi yang terdiri dari direktur noneksekutif, yang mayoritas independen, dengan tanggung jawab untuk mengajukan calon baru kepada dewan dan untuk menilai kinerja direksi secara berkelanjutan. Keputusan tentang pencalonan harus menjadi tanggung jawab dewan secara penuh setelah mempertimbangkan rekomendasi komite tersebut. Secara rinci tugas dan tanggungjawab komite nominasi adalah :

1) merekomendasikan kepada dewan, semua calon direktur untuk diisi oleh pemegang saham atau dewan. Dalam membuat rekomendasinya, Komite nominasi harus mempertimbangkan keterampilan, pengetahuan, keahlian dan pengalaman; profesionalisme; serta integritas calon. Dalam menominasikan kandidat untuk posisi direksi non-eksekutif independen, komite nominasi juga harus mengevaluasi kemampuan calon untuk melaksanakan 
tanggung jawab yang diharapkan sebagai direksi non-eksekutif independen

2) merekomendasikan kepada dewan, komisaris yang akan menjadi anggota komite-komite yang dibentuk dewan.

3) menelaah persyaratan keterampilan dan pengalaman anggota dewan termasuk kompetensi pokok komisaris harus di informasikan. Persyaratan ini harus diungkapkan dalam laporan tahunan.

4) melaksanakan proses yang telah ditetapkan dewan untuk menilai efektivitas dewan secara keseluruhan, dewan komite, dan untuk menilai kontribusi masing-masing direktur, termasuk direktur non-eksekutif independen, serta chief executive officer. Semua penilaian dan evaluasi yang dilakukan harus didokumentasikan dengan baik. 


\section{Fungsi Internal Audit}

Pentingnya fungsi internal audit ditunjukan dengan adanya kewajiban bagi dewan untuk membentuk fungsi audit internal dan menunjuk seorang ketua internal audit. Fungsi audit internal harus independen dari kegiatan yang mereka audit dan harus dilakukan secara independen dan profesional. Ketua audit internal bertanggung jawab atas review yang dilakukan secara reguler dan/atau menilai efektivitas manajemen risiko, pengendalian internal, dan tata kelola perusahaan. Untuk menjaga independensi fungsi internal audit, ketua audit internal harus menyampaikan laporannya langsung kepada komite audit.

\section{Etika Bisnis dan Pedoman Perilaku}

Dalam Pedoman Good Corporate Governance tersebut tidak terdapat ketentuan yang mengatur mengenai keberadaan etika bisnis dan pdoman perilaku (code of conduct) yang harus dimiliki dan dilaksanakan oleh perusahaan. 


\section{Remunerasi Direksi dan Dewan Komisaris}

Tingkat remunerasi harus cukup menarik untuk mempertahankan anggota dewan yang diperlukan untuk mengelola perusahaan dengan baik. Komponen remunerasi harus terstruktur dan dikaitkan dengan kinerja perusahaan. Khusus untuk direksi, remunerasi juga harus dikaitkan dengan kinerja individu sedangkan untuk komisaris tingkat remunerasi harus mencerminkan pengalaman dan tingkat tanggung jawab yang dilakukan oleh anggota komisaris tersebut. Selanjutnya perusahaan harus menetapkan prosedur formal dan transparan untuk menentukan kebijakan remunerasi bagi direksi dan dewan komisaris. Rincian jumlah remunerasi masing-masing anggota dewan komisaris dan direksi harus diungkapkan dalam laporan tahunan perusahaan.

\section{Pedoman Corporate Governance di Thailand}

\section{Metode Penerapan Pedoman Good Corporate Governance}


Metode penerapan Pedoman Good

Corporate Governance di Thailand bersifat Comply or Explain . Oleh karena itu, Stock Exchange of Thailand (SET) mengharapkan perusahaan untuk mengikuti Pedoman Good Corporate Governance tersebut. Selain itu, perusahaan dapat mengadaptasi prinsip-prinsip Good Corporate Governance sesuai kebutuhan fungsional tiap perusahaan. Bagi perusahaan yang memilih untuk tidak mematuhi prinsip Good Corporate Governance, diharuskan menjelaskan secara rinci alasan untuk tidak menerapkannya.

Perusahaan Tercatat telah diminta untuk mulai mengungkapkan pelaksanaan prinsip-prinsip Good Corporate Governance pada tahun 2007 pada Laporan Tahunan perusahaan. Selain itu, perusahaan yang terdaftar harus mengungkapkan penerapan prinsip-prinsip tata kelola perusahaan yang baik (Good Corporate Governance) melalui media komunikasi yang yang paling nyaman bagi Perusahaan, pemegang saham, investor, stakeholder lainnya dan pihak-pihak terkait. Salah 
satu saluran yang disarankan adalah situs web perusahaan.

\section{Sanksi atas ketidakpatuhan}

Penerapan Pedoman Good Corporate Governance oleh perusahaan hanya bersifat voluntary. Oleh karena itu, tidak ada sanksi bagi perusahaan yang tidak menerapkannya. Akan tetapi, perusahaan harus menjelaskan dengan rinci alasan untuk tidak menerapkannya.

\section{Ruang lingkup Pedoman Good Corporate Governance}

Prinsip-prinsip dan praktek-praktek terbaik Good Corporate Governance Perusahaan tercatat yang direkomendasikan oleh SET (Stock Exchange of Thailand) mencakup 5 kategori yaitu,

a. Hak Pemegang Saham (Rights of Shareholders)

b. Perlakuan Adil kepada Pemegang Saham (Equitable Treatment of Shareholders) 
c. Peran Pemangku Kepentingan (Role of Stakeholders)

d. Keterbukaan dan Transparansi (Disclosure and Transparency)

e. Tanggung Jawab Dewan Direksi (Responsibilities of the Board)

\section{Komposisi/jumlah, dan persyaratan}

\section{Komisaris Independen}

Dewan direksi, dengan persetujuan dari rapat pemegang saham, harus menetapkan jumlah anggota dan komposisi. Harus ada sejumlah direktur independen yang setidaknya setara dengan sepertiga dari jumlah dewan, tetapi tidak kurang dari 3. Direksi yang tersisa pada board merupakan perwakilan dari setiap kelompok pemegang saham, jumlah direksi harus proporsional dengan kepemilikan masing-masing kelompok.

\section{Komposisi/jumlah Direksi}

Dewan memainkan peran penting dalam tata kelola perusahaan untuk kepentingan terbaik 
perusahaan. Dewan ini bertanggung jawab kepada pemegang saham dan manajemen independen. Dewan harus memiliki kepemimpinan, visi, dan kemandirian dalam pengambilan keputusan untuk kepentingan terbaik perusahaan dan seluruh pemegang saham. Dewan secara jelas harus memisahkan peran dan tanggung jawabnya dari manajemen dan memantau operasi perusahaan untuk memastikan bahwa semua kegiatan yang dilakukan sesuai dengan hukum yang relevan dan standar etika.

Struktur dewan harus terdiri dari director dengan berbagai kualifikasi, keterampilan, pengalaman, dan keahlian yang berguna untuk perusahaan. Direksi harus melaksanakan tugas mereka dengan itikad baik, dengan due diligence and care, untuk kepentingan terbaik perusahaan dan seluruh pemegang saham. Agar direksi dapat melakukan tugas mereka, direksi harus menerima informasi yang benar dan lengkap.

Struktur Dewan diatur sebagai berikut : 
a. Dewan direksi, dengan persetujuan dari rapat pemegang saham, harus menetapkan jumlah anggota dan komposisi. Harus ada sejumlah direktur independen yang setidaknya setara dengan sepertiga dari jumlah dewan, tetapi tidak kurang dari 3 . Direksi yang tersisa pada board merupakan perwakilan dari setiap kelompok pemegang saham, jumlah direksi harus proporsional dengan kepemilikan masing-masing kelompok.

b. Masa jabatan direksi harus secara jelas dinyatakan dalam kebijakan tata kelola perusahaan (company's corporate governance policy).

c. Anggota dewan perusahaan yang terlalu banyak digunakan untuk mengisi komposisi dewan mungkin tidak dapat melakukan tugasnya secara efektif. Dewan dapat mengetahui efektivitas anggota Dewan dengan membatasi jumlah direksi dalam 
Dewan. Perusahaan harus mengungkapkan informasi tentang posisi keanggotaan direksi kepada pemegang saham.

d. Dewan harus menyatakan dengan jelas kebijakan dan prosedur mengenai posisi dewan di perusahaan lain yang dimiliki oleh direktur perusahaan dan eksekutif puncak, baik dalam segi jenis direktur (eksekutif misalnya, di luar, atau independen) dan jumlah posisi dewan yang dapat dipegang. Misalnya, dewan mungkin menyatakan bahwa jabatan Dewan pada perusahaan lain yang dimiliki oleh direktur perusahaan harus disetujui oleh dewan.

e. Peran dan tanggung jawab ketua dewan berbeda dari managing director. Dewan harus memisahkan peran dan tanggung jawab dari kedua posisi. Dalam rangka untuk mencapai keseimbangan kekuasaan, dua posisi tersebut harus dipegang oleh individu yang berbeda. 
f. Ketua dewan harus merupakan komisaris independen.

Pelatihan bagi Dewan dan Manajemen perusahaan :

a. Dewan harus mendorong dan memfasilitasi pelatihan untuk semua pihak internal yang berhubungan dengan tata kelola perusahaan seperti anggota dewan komisaris, anggota komite audit, anggota direksi, sekretaris perusahaan dll. Pelatihan akan memungkinkan mereka untuk terus meningkatkan kinerja mereka. Hal ini dapat berupa training internal maupun eksternal.

b. Anggota dewan yang baru harus dilengkapi dengan semua dokumen dan informasi yang berguna untuk melakukan tugas mereka. Pengantar bisnis dan operasi perusahaan yang diperlukan.

c. Dewan harus meminta komisaris untuk mempresentasikan perencanaan suksesi 
secara teratur. Eksekutif puncak dan managing director seharusnya menetapkan pengganti dalam kasus jika mereka tidak dapat melakukan tugas mereka.

d. Dewan harus membentuk program pengembangan eksekutif. Direktur harus melaporkan ke dewan setiap tahun tentang program. Dewan harus mempertimbangkan pengembangan eksekutif ketika membahas rencana suksesi.

\section{Komite yang dibentuk Komisaris}

Untuk efisiensi dan efektivitas, dewan direksi membentuk komite untuk mempelajari dan memonitor tugas-tugas tertentu atas nama dewan direksi, khususnya isu-isu yang perlu pendapat bias. Komite harus memiliki lingkup kerja yang jelas, peran dan tanggung jawab pekerjaan mereka dan prosedur kerja seperti rapat dan pelaporan kepada Dewan Direksi. Beberapa prinsip yang direkomendasikan terkait komite yang akan dibentuk yaitu: 
a. Komite harus transparan dan independen dalam menjalankan tugasnya

b. Mayoritas anggota komite harus komisaris independen

c. Ketua komite harus merupakan komisaris independen

d. Ketua Dewan seharusnya tidak menjadi ketua atau anggota komite apapun untuk memastikan independensi komite.

Stock Exchange Rule (SET) mengharuskan setiap perusahaan memiliki Komite Audit. Selain itu, Pedoman GCG juga merekomendasikan dua Komite lainnya yaitu: Komite Remunerasi dan Komite Nominasi.

a. Komite Remunerasi bertanggung jawab untuk menetapkan kriteria dan bentuk pembayaran kepada dewan dan eksekutif puncak dan menyajikan hasilnya kepada dewan. Sementara dewan menyetujui remunerasi eksekutif, para pemegang 
saham menyetujui remunerasi anggota dewan.

b. Komite Nominasi bertanggung jawab untuk menetapkan kriteria dan proses pencalonan anggota dewan dan eksekutif puncak, memilih calon yang memenuhi syarat sesuai dengan pre-determined kriteria dan proses, dan menyajikan hasilnya ke dewan. Kemudian, dewan akan menyajikan hasilnya pada rapat pemegang saham untuk pemilihan anggota dewan dan eksekutif puncak.

Beberapa ketentuan yang berlaku bagi komitekomite yang dibentuk sebagai berikut

a. Dalam melakukan tugasnya, komite harus transparan dan independen, mayoritas anggota komite harus komisaris independen. Ketua komite harus merupakan komisaris independen. 
b. Ketua Dewan seharusnya tidak menjadi ketua atau anggota komite apapun untuk memastikan independensi komite.

\section{Fungsi Internal Audit}

Dewan direksi harus memastikan bahwa sistem pengendalian internal perusahaan, termasuk keuangan, kepatuhan, dan kontrol kebijakan, dan meninjau sistem setidaknya setiap tahun. Dewan juga harus menetapkan seseorang atau suatu departemen untuk melakukan audit secara independen dan melaporkan kepada dewan.

\section{Etika Bisnis dan Pedoman Perilaku}

Dewan harus memastikan bahwa code of conduct perusahaan dibuat secara tertulis agar semua direktur, eksekutif dan karyawan memahami standar etika bisnis perusahaan. Kepatuhan terhadap code of conduct perusahaan harus diawasi secara ketat oleh dewan. Di samping itu perusahaan juga harus mengadopsi pedoman internal yang mengatur mengenai hal-hal yang 
membutuhkan persetujuan dewan, dan menentukan pengungkapan jenis transaksi material yang memerlukan persetujuan dewan.

\section{Remunerasi Direksi dan Dewan Komisaris}

Remunerasi Dewan harus sebanding dengan tingkat industri di mana perusahaan beroperasi, mencerminkan pengalaman, kewajiban, ruang lingkup kerja, akuntabilitas dan tanggung jawab serta kontribusi masing-masing direktur. Anggota dewan yang ditugaskan untuk tugas-tugas yang lebih, seperti komite, harus dibayar lebih. Disamping itu remunerasi direktur eksekutif dan manajemen puncak harus sesuai dengan kebijakan dewan dalam batas yang disetujui oleh pemegang saham. Untuk kepentingan perusahaan, gaji eksekutif, bonus, dan kompensasi jangka panjang lainnya harus sesuai dengan kinerja perusahaan dan eksekutif masing-masing.

Semua komisaris atau komite remunerasi harus menilai kinerja Direksi setiap tahun untuk menetapkan jumlah kompensasi nya. Dasar 
penilaian harus disetujui oleh dewan sebelum evaluasi. Kriteria harus obyektif, termasuk kinerja keuangan, kinerja strategis jangka panjang, rencana pengembangan karir, dll. Penilaian ini harus disampaikan kepada dewan untuk disetujui. Ketua dewan atau komisaris utama harus menyerahkan hasil evaluasi kepada dewan.

Keterbukaan informasi mengenai remunerasi board meliputi 'kebijakan remunerasi direksi dan eksekutif sesuai dengan kontribusi dan tanggung jawab setiap orang, bentuk dan jumlah pembayaran. Jika ada direktur perusahaan yang juga merupakan direktur anak perusahaan, maka jumlah biaya yang dibayarkan oleh anak perusahaan kepada direksi tersebut harus diungkapkan juga.

\section{E. Pedoman Corporate Governance di Philipina}

Sesuai dengan kebijakan Negara untuk secara aktif mempromosikan reformasi tata kelola perusahaan yang bertujuan untuk meningkatkan 
kepercayaan investor, mengembangkan pasar modal dan membantu mencapai pertumbuhan yang tinggi dan berkelanjutan untuk sektor korporasi dan ekonomi, Securities Commission, melalui Resolusi No.135, Seri 4 April 2002, menyetujui berlakunya dan pelaksanaan Pedoman Good Corporate Governance ini. Pedoman ini berlaku untuk perusahaan efek yang tercatat atau terdaftar, perusahaan penerima izin/lisensi dan perusahaan publik. Pedoman Good Corporate Governance ini juga berlaku untuk cabang atau anak perusahaan dari perusahaan asing yang beroperasi di Filipina yang terdaftar atau listed.

\section{Metode Penerapan Pedoman Good Corporate Governance}

Penerapan Pedonam Good Corporate Governance di Philipina merupakan suatu kewajiban. Penegakan hukum atas pelaksanaan Pedoman Good Corporate Governance tersebut dilakukan oleh Securities and Exchange Commission dan dapat dikenakan sanksi. Bursa 
Efek Philipina mewajibkan perusahaan tercatat untuk melaporkan secara periodik mengenai kepatuhan terhadap manual tata kelola termasuk hal-hal yang belum dapat dipenuhi wajib diungkapkan lengkap dengan alasannya.

2. Sanksi atas ketidakpatuhan terhadap Pedoman Good Corporate Governance

Kegagalan untuk mengadopsi manual tata kelola perusahaan seperti yang ditentukan untuk perusahaan, setelah pemberitahuan waktu dan alasan jatuh tempo dikenakan denda sebesar P100, 000.00.

\section{Ruang lingkup Pedoman Good Corporate} Governance
a. The Board Governance
b. Supply Information
c. Accountability and Audit

d.Stockholders' Rights and Protection of Minority Stockholders' Interests 

e. Evaluation Systems
f. Disclosure and Transparency
g. Commitment to Corporate Governance
h. Administrative Sanction

\section{Komposisi dan persyaratan Komisaris Independen}

Perusahaan publik harus memiliki minimal dua (2) direktur independen atau sedikitnya dua puluh persen (20\%) dari jumlah anggota dewan. Semua perusahaan didorong untuk memiliki direktur independen. Dewan harus menjaga keseimbangan jumlah anggotanya yang mencakup direktur eksekutif dan direkrur non-eksekutif (termasuk non-eksekutif independen). dewan harus memiliki pembagian jawab tanggung yang jelas sehingga tidak ada individu atau kelompok yang dapat mendominasi pengambilan keputusan Dewan. Para direktur non-eksekutif harus memiliki kualifikasi yang cukup, dan memiliki peranan yang penting dalam pengambilan keputusan dewan. 
direktur non-eksekutif independen dipertimbangkan oleh Dewan dan harus diidentifikasi dalam laporan tahunan.

\section{Komposisi/jumlah Direksi}

Dewan setidaknya terdiri dari lima (5) orang tetapi tidak lebih dari lima belas (15) anggota yang dipilih oleh pemegang saham. Perusahaan publik harus memiliki minimal dua (2) komisaris independen atau sedikitnya dua puluh persen (20\%) dari jumlah anggota dewan. Semua perusahaan didorong untuk memiliki komisaris independen. Dewan harus menjaga keseimbangan jumlah anggotanya yang mencakup executive director (direksi) dan non-executive director (komisaris, termasuk komisaris independen).

Dewan harus memiliki pembagian jawab tanggung yang jelas sehingga tidak ada individu atau kelompok yang dapat mendominasi pengambilan keputusan Dewan. Para direktur non-eksekutif harus memiliki kualifikasi yang cukup, dan memiliki 
peranan yang penting dalam pengambilan keputusan dewan.

Dewan dapat mempertimbangkan pedoman tentang jumlah direktur. pada umumnya Jumlah optimal direktur terkait dengan kapasitas direktur untuk melaksanakan tugasnya dengan tekun.

Peranan Chairman of Board dan Chief Executive Officer dilakukan secara terpisah untuk menjamin perimbangan kekuasaan, meningkatkan akuntabilitas dan kapasitas yang lebih besar dari Dewan untuk pengambilan keputusan yang independen. Perusahaan harus mengungkapkan hubungan antara Ketua dan CEO pada saat pemilihan mereka. ketika kedua posisi Ketua dan CEO disatukan, maka harus secara jelas ada seorang pemimpin untuk memberikan visi dan misi tunggal. Dalam hal ini, checks and balances harus jelas disediakan untuk membantu memastikan keindependenannya, pandangan luar, perspektif, dan memberikan penilaian tepat pada saat sidang Dewan. 
Dewan dapat memberikan kualifikasi tambahan untuk direktur, namun tidak terbatas pada hal-hal sebagai berikut:

a. Pendidikan yang memadai

b. Kompetensi dan pemahaman tentang bisnis yang memadai

c. Persyaratan umur

d. Integritas / kejujuran

e. Ketekunan

\section{Komite yang dibentuk Komisaris}

Dewan membentuk komite-komite untuk membantu pelaksanaan Tata Kelola perusahaan yang baik.

\section{a. Komite Audit}

Ketua komite audit harus merupakan direktur independen. Ketua komite audit harus bertanggung jawab menanamkan dalam pikiran anggota Dewan pentingnya tanggung jawab manajemen dalam mempertahankan sistem pengendalian internal dan tanggung jawab pengawasan Dewan. Cabang atau 
anak dari perusahaan asing di Filipina harus mengikuti standar ini. Ketua komite audit perusahaan tersebut harus independen, dan harus melapor kantor pusat perusahaan.

Komite Audit terdiri dari sedikitnya tiga (3) anggota Dewan, sebaiknya dengan latar belakang akuntansi dan keuangan, salah satu merupakan direktur independen dan lainnya harus mempunyai pengalaman audit.

Komite audit mempunyai fungsi spesifik sebagai berikut:

1) Memberikan pengawasan atas kegiatan manajemen senior dalam mengelola kredit, pasar, likuiditas, operasional, hukum dan risiko lain atas perusahaan. fungsi ini harus termasuk menerima informasi dari manajemen senior secara berkala tentang eksposur risiko dan manajemen risiko.

2) melakukan pengawasan atas auditor internal perusahaan dan eksternal; 
3) mereview dan menyetujui ruang lingkup audit, frekuensi, dan rencana tahunan audit internal;

4) Diskusi dengan auditor eksternal sebelum audit dimulai sesuai dengan sifat dan ruang lingkup audit, dan memastikan koordinasi karna melibatkan lebih dari satu perusahaan audit yang terlibat;

5) Bertanggung jawab atas pengaturan departemen internal audit dan mempertimbangkan penunjukan auditor internal serta auditor eksternal independen, biaya audit dan semua pertanyaan pengunduran diri atau pemecatan;

6) Memantau dan mengevaluasi kecukupan dan efektivitas sistem pengendalian internal korporasi;

7) Menerima dan menelaah laporan auditor internal dan eksternal dan badan regulasi, dan memastikan manajemen mengambil 
tindakan koreksi yang tepat, pada waktu yang tepat dalam menangani fungsi kontrol dan kepatuhan terhada peraturan regulator;

8) Review triwulanan, laporan keuangan tengah tahun dan tahunan sebelum diserahkan kepada Dewan, dengan fokus terutama pada:

a) Setiap perubahan dalam kebijakan akuntansi dan prakteknya;

b) Area-area yang memerlukan penilaian (Major judgmental areas)

c) penyesuaian yang signifikan dari audit

d) asumsi-asumsi going concern perusahaan

e) Kesesuaian dengan standar akuntansi

f) Kepatuhan pajak, hukum, dan persyaratan bursa

9) Bertanggung jawab atas koordinasi, monitoring dan memfasilitasi kepatuhan terhadap hukum dan peraturan. Ini juga 
mungkin merupakan tujuan dari Unit Kepatuhan.

10) Mengevaluasi dan menentukan pekerjaan non-audit oleh auditor eksternal dan menjaga dalam peninjauan audit non-biaya yang dibayar kepada auditor eksternal sehubungan dengan total pengeluaran perusahaan untuk konsultasi. Pekerjaan non-audit harus diungkapkan dalam laporan tahunan.

11) Menetapkan dan mengidentifikasi pelaporan tugas dan tanggung jawab audit internal oleh kepala audit eksekutif. Komite Audit harus memastikan bahwa auditor internal harus memiliki akses yang bebas dan penuh ke semua catatan perusahaan, properti dan personel yang relevan dengan aktivitas audit internal dan aktivitas audit internal harus bebas dari campur tangan manajemen dalam menentukan ruang lingkup pemeriksaan audit internal, bekerja dan 
berkomunikasi, dan menyediakan tempat bagi Komite Audit untuk meninjau dan menyetujui rencana audit internal tahunan.

\section{b. Komite Nominasi}

Dewan dapat membentuk komite remunerasi yang terdiri dari setidaknya tiga(3) orang anggota, salah satunya harus merupakan direktur independen untuk meninjau dan mengevaluasi kualifikasi orang yang dinominasikan Dewan serta mereka yang dicalonkan untuk posisi anggota Dewan dan memberikan penilaian pada Board dalam melakukan proses penggangkatan dan penggantian anggota dewan.

\section{c. Komite Kompensasi atau Remunerasi}

Dewan dapat membentuk komite remunerasi dimana paling sedikit terdiri dari tiga (3) anggota, salah satunya harus direktur independen. Komite ini bertugas menetapkan prosedur formal dan transparan dalam mengembangkan kebijakan remunerasi eksekutif dan untuk menetapkan paket 
remunerasi pejabat perusahaan dan direksi, dan memberikan pengawasan terhadap remunerasi manajemen senior dan personil kunci lainnya, memastikan kompensasi yang konsisten dengan budaya korporasi, strategi dan pengendalian lingkungan.

\section{Fungsi Internal Audit}

Setiap perusahaan harus membentuk fungsi audit independen, dimana dewan, manajemen senior dan pemegang saham dapat memberikan tugas untuk melakukan tugas pengendalian perusahaan secara efektif, tepat dan ditaati. Dewan dapat menunjuk seorang ketua eksekutif audit untuk melaksanakan fungsi audit, dan melaporkannya kepada perusahaan. Kepala audit Eksekutif harus melaporkan secara langsung kepada Komite audit.

Manajemen juga dapat membentuk suatu sistem evaluasi kinerja untuk mengukur kinerja Dewan dan manajemen eksekutif perusahaan. Pembentukan sistem evaluasi tersebut, termasuk 
fiturnya, dapat diungkapkan dalam laporan tahunan perusahaan.

\section{Etika Bisnis dan Pedoman Perilaku}

Perusahaan harus mengumumkan dan menetapkan peraturan tata kelola perusahaan dan prinsip-prinsip sesuai dengan Kode Etik ini. Peraturan harus dalam bentuk manual dan tersedia sebagai referensi bagi direksi. Ha Ini harus disampaikan kepada Komisi yang akan mengevaluasi kepatuhan dengan mempertimbangkan Kode Etik ini, dan mempertimbangkan ukuran dan sifat usaha perusahaan. Ketua Dewan bertugas dan bertanggung jawab untuk menjamin kepatuhan terhadap praktek dan kode tata kelola perusahaan kecuali diamanatkan oleh hukum.

\section{Remunerasi Direksi dan Komisaris}

Tingkat remunerasi harus cukup untuk menarik dan mempertahankan direksi, jika ada, dan personil yang diperlukan untuk menjalankan 
perusahaan dengan sukses. bagaimanapun perusahaan harus menghindari membayar lebih dari apa yang diperlukan untuk tujuan ini. proporsi remunerasi direktur eksekutif dapat berupa hadiah sebagi penghargaan terhadap kinerja perusahaan dan individu.

Perusahaan dapat menetapkan prosedur formal dan transparan untuk mengembangkan kebijakan remunerasi eksekutif dan untuk menetapkan paket remunerasi masing-masing direksi dan petugas jika ada. Direktur tidak harus terlibat dalam menentukan remunerasi sendiri.

Dalam laporan tahunan perusahaan, informasi dan pernyataan harus mencakup pengungkapan yang jelas, ringkas dan mudah dimengerti, semua rencana dan non-rencana kompensasi yang diberikan kepada siapa, diterima oleh siapa, dibayarkan kepada siapa, atau diperkirakan dibayarkan kepada siapa, langsung atau tidak langsung untuk setiap orang yang berfungsi sebagai CEO atau bertindak dalam 
kapasitas yang sama selama tahun fiskal terakhir selesai.

Untuk melindungi dana perusahaan, komite perusahaan dapat mengatur cara pembayaran kompensasi, tunjangan, jasa dan tunjangan kepada direksi dan manajer dalam kasus yang sangat luar biasa, misalnya, ketika perusahaan berada di bawah kurator atau rehabilitasi. 


\section{DAFTAR PUSTAKA}

Arifin, 2005. Peran Akuntan Dalam Menegakkan Prinsip Corporate Governance

Perusahaan di Indonesia, Sidang Senat Guru Besar Fakultas Ekonomi Universitas Diponegoro, Semarang.

Adam, Tim and Goyal. Vidhan. K, 2003. " The Investment Opportunity Set and its Proxy Variabies: Theory and Evidence",Hong kong University of Science and Technology.

Code of Corporate Governance 2005, Bursa Efek Singapura.

Code Of Corporate Governance, SEC Memorandum Circular No. 2 Series of 2002, Philipina.

Forum for Corporate Governance in Indonesia. 2001. Seri Tata Kelola (Corporate Governance) Jilid II. http://fcgi.org.id.

Freeman, 1984. Strategic Management : A Stake Holder Theory, Cambridge University Press New York

Lasdini Purwanti dkk (2010), Kajian Tentang pedoman Corporate Governance di Negara- 
Negara Anggota ACMF, BAPEPAM-LK Kementerian Keuangan Republik Indonesia.

Bangun, Astri Kharina, Kontan.co.id, BEl tantang transparansi BUMN di bursa, <http:// investasi.kontan.co.id/news/bei-tantangtransparansi-bumn-di-bursa>

Iman, Firdaus Nur, Indonesia Finance Today, Perusahaan BUMN Masih Takut TransparansiLaporanKeuangan,http://www.in donesiafinancetoday.com/read/32112/Perusa haan- BUMN-Masih-Takut-TransparansiLaporan-Keuangan>

International Finance Corporation (2014), The Indonesian Corporate Governance Manual, First Edition, IFC dan OJK, Jakarta.

Haris Wibisono. (2004). Pengaruh Earnings Management Terhadap Kinerja Di Seputar SEO. Tesis S2. Magister Sains Akuntansi UNDIP. Tidak dipublikasikan

Jensen, Michael C\&Meckling, William H., 1976," Theory of the Finn: Managerial Behavior, Agency Costs, and Ownership Structure", Journal of Financial Economics, Vol 3 No 4, October, pp 305-360. 
Kurniawan, Dudi M., and Nur Indriantoro, (2000) 'Corporate Governance in Indonesi, Paper on The Second Asian Roundtable on Corporate Governance 9, <http://www.oecd. org/dataoecd/6/62/1931154.pdf>

Nugroho and Wrihatnolo, Kementerian PPN/Bappenas, Pengalaman Revitalisasi BUMN,<http://www.bappenas.go.id/pencarian/ global/?keyword=pengalaman+revitalisasi+bu mn\&task=Cari $>$

Rahmawati dan Puteri, 2006. Pengaruh Corporate Governance, Kepemilikan Manajerial, Proporsi Dewan Komisaris dan Komite Audit Terhadap Manajemen laba dan Kinerja Perusahaan.Repository USU, Medan

Shleifer dan Vishny, 1997. Legal Determinan of External Finance. The Journal of Finance Vol LII No 3.

Rizal, M., Detikcom, Yanuar Rizky: Permainan Krakatau Steel Paling Gila-gilaan, <http:// news.detik.com/read/2010/11/29/130643/1504 762/159/yanuar-rizky-permainan-krakatausteel-paling-gila-gilaan>

Susanto, Heri and Syahid Latif, Viva News, Menkeu-Menneg BUMN Berebut Saham Minoritas, 
$<\mathrm{http}: / /$ dunia.news.viva.co.id/news/read/17440

7-menkeu-bumn--berebut-- saham-minoritas>

Suara Pembaruan, DPR Minta Pengangkatan Direksi

Dibatalkan, $<$ http:// www.suarapembaruan.com/home/dpr-mintapengangkatan-direksi-bumndibatalkan/18471>

Sunarto, 2003. Prilaku Organisasi, Amus, Jakarta

Surya, Indra dan Yustiavandana, Ivan. 2006. Penerapan Good Corporate Governance: Mengesampingkan Hak-hak demi Kelangsungan Usaha.Edisi Pertama. Jakarta: Kencana.

Pedoman Good Corporate Governance Tahun 2006 - Komite Nasional Kebijakan Corporate Governance.

Peraturan Bapepam-LK Nomor IX.I.5 tentang Pembentukan dan Pedoman Pelaksanaan Kerja Komite Audit.

Peraturan Bapepam-Lk Nomor IX.I.7:Pembentukan dan pedoman penyusunan piagam unit audit internal.

Peraturan Bapepam-LK Nomor X.K.6 tentang Kewajiban Penyampaian Laporan Tahunan bagi Emiten dan Perusahaan Publik. 
Tjager et.al (2003). "Corporate Governance: Tantangan dan Kesempatan bagi Komunitas Bisnis Indonesia". PT.Prenhallindo, Jakarta.

The Malaysian Code on Corporate Governance, tahun 2007 diterbitkan oleh Bursa Efek Malaysia.

The Principles of Good Corporate Governance for Listed Companies, tahun 2006, Bursa Efek Thailand.

Ujiyantho, Muh. Arief dan Pramuka, Bambang Agus. 2007. "Mekanisme Corporate Governance, Manajemen Laba dan Kinerja keuangan". Simposium Nasional Akuntansi X Makasar. AKPM-01.

Verrecchia, 2001. Essay on Disclousure. Journal of Accounting and Economics 32 (2001) 


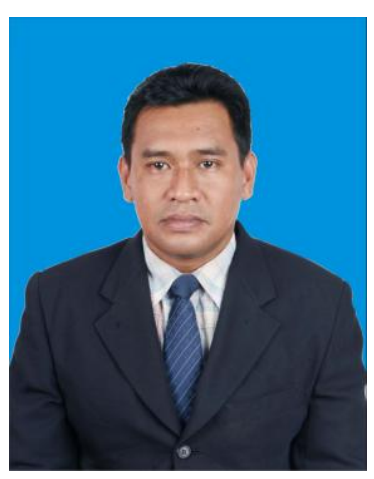

DR. MUHAMMAD NASRUM AKAL, SE., MM. Anak dari pasangan $($ Alm $) \mathrm{H}$. Andi. M. Akal Mallu dan (Alm) $\mathrm{Hj}$. Andi Sitti Rukiah, lahir di Dusun Tobonggae Cempaniga Kecamatan Camba Kabupaten Maros pada 21 Maret 1971. Anak kelima dari enam bersaudara ini menempuh pendidikan mulai dari TK s/d SMA di Kecamatan Camba dan berhasil tamat di SMA Negeri Lappamario Camba. Kemudian melanjutkan pendidikan pada Fakultas Ekonomi Universitas Muslim Indonesia Program Studi Manajemen Perusahaan. Pada tahun 2000 melanjutkan pendidikan pada Program Magister (S2) pada Universitas Hasanuddin Makassar dan menyelesaikan Program Doktoral (S3) IImu Ekonomi pada Program Pascasarjana Universitas Hasanuddin Makassar pada tahun 2012. Mengikuti Program Sandwich pada tahun 2008 di Phd Program Collage Businees of Administration (CBA) University of the Philippines, Queson City, Diliman. Kesehariannya bekerja sebagai Dosen Tetap Yayasan pada Sekolah Tinggi IImu Manajemen (STIM) YAPIM Maros. Menjabat sebagai Ketua STIM YAPIM Maros periode I 2009 2013 dan periode II 2013-2017. Selain itu mengajar pada beberapa perguruan tinggi. Suami dari Ir, Andi Herwati Marwan, M.Si ini dikararuniai tiga orang anak: Andi Tenri Sapada, Andi Mappincara dan Andi Batara Lipu.

Buku :

1. Otonomi dan Pembangunan Keuangan Daerah (Konsep, Kebijakan dan Implementasi, 2013. Penulis) 
2. Lima Tahun Wakil Rakyat Bersama Pemerintah Daerah Kolaka Utara, 2014 (Penyunting)

3. Corporate Governance, (Konsep, Teori dan Perbandingan Pelaksanaan Beberapa Negara Asia, 2014. Penulis)

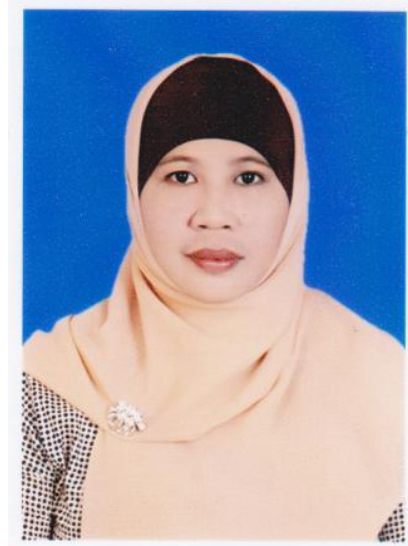

HJ. ANDI TENRI ULENG

AKAL, SE., MM Lahir di Camba kabupaten Maros, Sulawesi Selatan pada tanggal 03 Maret 1969. Lahir dari pasangan (Alm) $\mathrm{H}$. Andi Akal Mallu dan (Alm) $\mathrm{Hj}$. Andi Sitti Rukuah. Menempuh pendidikan SD sampai dengan SMP di Kecamatan Camba, Kemudian melanjutkan SMA di Maros. Melanjutkan pendidikan tinggi :

1. Strata Satu (S1) di Universitas Muslim Indonesia (UMI) pada tahun 1987-1992

2. Strata Dua (S2) di Program Pasca Sarjana Universitas Muslim Indonesia (UMI) pada tahun 2000-2002 
3. Program Doktor (S3) Ilmu Manajemen Pasca Sarjana Universitas Muslim Indonesia (UMI) pada tahun 2013-Sekarang.

Sekarang ini berkerja sebagai dosen Kopertis Wilayah IX Sulawesi DPK pada Sekolah Tinggi IImu Manajemen YAPIM Maros. 